\title{
38. MESOZOIC SEQUENCES OF THE CENTRAL NORTH ATLANTIC
}

\author{
Lubomir Jansa, Bedford Institute of Oceanography, Dartmouth, Nova Scotia, Canada, \\ James V. Gardner, U.S. Geological Survey, Menlo Park, California, \\ and \\ Walter E. Dean, U.S. Geological Survey, Denver, Colorado
}

\section{INTRODUCTION}

The Mesozoic sequences off the west coast of Africa investigated on Deep Sea Drilling Project (DSDP) Leg 41 resemble, in many aspects, coeval sedimentary rocks drilled in the western North Atlantic, and rocks exposed in the mountain ranges around the Mediterranean Sea. This is not unexpected and supports Bernoulli's (1972) and Bernoulli and Jenkyns' (1974) comparisons of the Mesozoic of the western North Atlantic basin and the Mediterranean region. Although the Jurassic-Cretaceous sequences in the North Atlantic and Mediterranean region reflect similar sedimentary and bathymetric evolution, the tectonic settings of these areas are different. The pelagic facies of the Alpine Mediterranean were deposited on: (1) a sunken Triassic-Late Jurassic carbonate platform as can be seen, for example, in the southern Alps (Trento zone in northern Italy) and the Betic Cordillera of southern Spain; and (2) ophiolite sequences, resembling oceanic crust (Laubscher, 1970), known from the Ligurian Apennines, Turkey, and Greece (Bernoulli and Jenkyns, 1974); the latter were tectonically deformed and thrusted on the continental margin of the Tethys as part of the nappe pile. In contrast, the Mesozoic sediments recovered during Legs 1, 11, and 41 from the central North Atlantic have been laid down on undeformed volcanic rocks, and the sedimentary sequences have not been significantly involved in any orogenic processes. Therefore, they represent an ideal setting for the study of the evolution of the North Atlantic basin and its relation to the paleogeographic and paleotectonic development of the Atlantic and Tethys regions. Furthermore, because these sediments do not suffer from diagenetic alterations caused by orogenic processes they provide excellent opportunities for studies of diagenesis.

In view of the excellent results obtained during Leg 41 and previous results in the North Atlantic, it is timely to attempt a lithologic synthesis of the southern North Atlantic basin and compare results with the sedimentary history of the adjacent continental margins. It should be stressed that the lithostratigraphic results obtained by deep-sea drilling in the central North Atlantic might sometimes be anomalous in that some holes were drilled over basement highs to assure basement penetration, and thus sampling might not always be entirely representative of the regional lithostratigraphy. In such situations the sedimentary sequences are condensed, and hiatuses and unconformities are more frequent than in the deeper parts of the basin. Also, the character of the basement in the deep parts of the basin may differ from the topographic highs over which the DSDP holes were located.

In this paper, Mesozoic lithostratigraphic units identified during Leg 41 are correlated with similar and approximately time synchronous lithofacies drilled during Legs 1 and 11 in the central North Atlantic. The correlations are based on analyses of cores, smear slides, and thin sections from Leg 41 , thin sections of selected rocks from Sites 100 and 105, and on a brief examination of cores from Leg 11. The comparison of these results with continental margin basins is based on an extensive subsurface study of the Mesozoic of the Scotian Shelf and Grand Banks area and brief reconnaissance studies of the exposed Mesozoic in Morocco, southern Spain, southern France, and northern Italy.

\section{STRUCTURAL SETTING}

The central North Atlantic Basin (Figure 1), excluding the zone of the Mid-Atlantic Ridge, can be considered a tectonically quiet region dominated by subsidence of the ocean basement, with only local uplift of volcanic islands such as Cape Verde Archipelago, Cape Verde rise area, Canary Islands, Bermuda, and others.

Basalt underlying Jurassic oceanic sediments in the southeastern Atlantic (Figure 2) was reached by drilling in the Cape Verde Basin at Site 367 (Plate 1, Figure 1), which was located within the quiet magnetic zone (Figure 1, Hayes and Rabinowitz, 1975). Basalts underlying Jurassic sedimentary sequences in the western North Atlantic were encountered at Sites 100 and 105 (Hollister et al., 1972). Site 100, in the Cat Gap area was located inside the quiet magnetic zones shoreward from magnetic anomaly M-25, which is the oldest anomaly of the Keathley sequence. Site 105 was also located just west of Keathley anomaly M-25 (Larson and Hilde, 1975).

None of the above sites penetrated basalt deep enough to be certain about the origin of the basalt, but some deductions can be made from the nature of the contacts with overlying sediments and from the textural characteristics of the basalts. The most significant feature is the lack of thermal metamorphism at the contact between basalts and the overlying sediments at Sites 100,105 , and 367 . In contrast, the contact of the basic sills penetrated during Leg 41 on the Cape Verde Rise (Site 368) has a well-developed, thermally metamorphosed zone. 


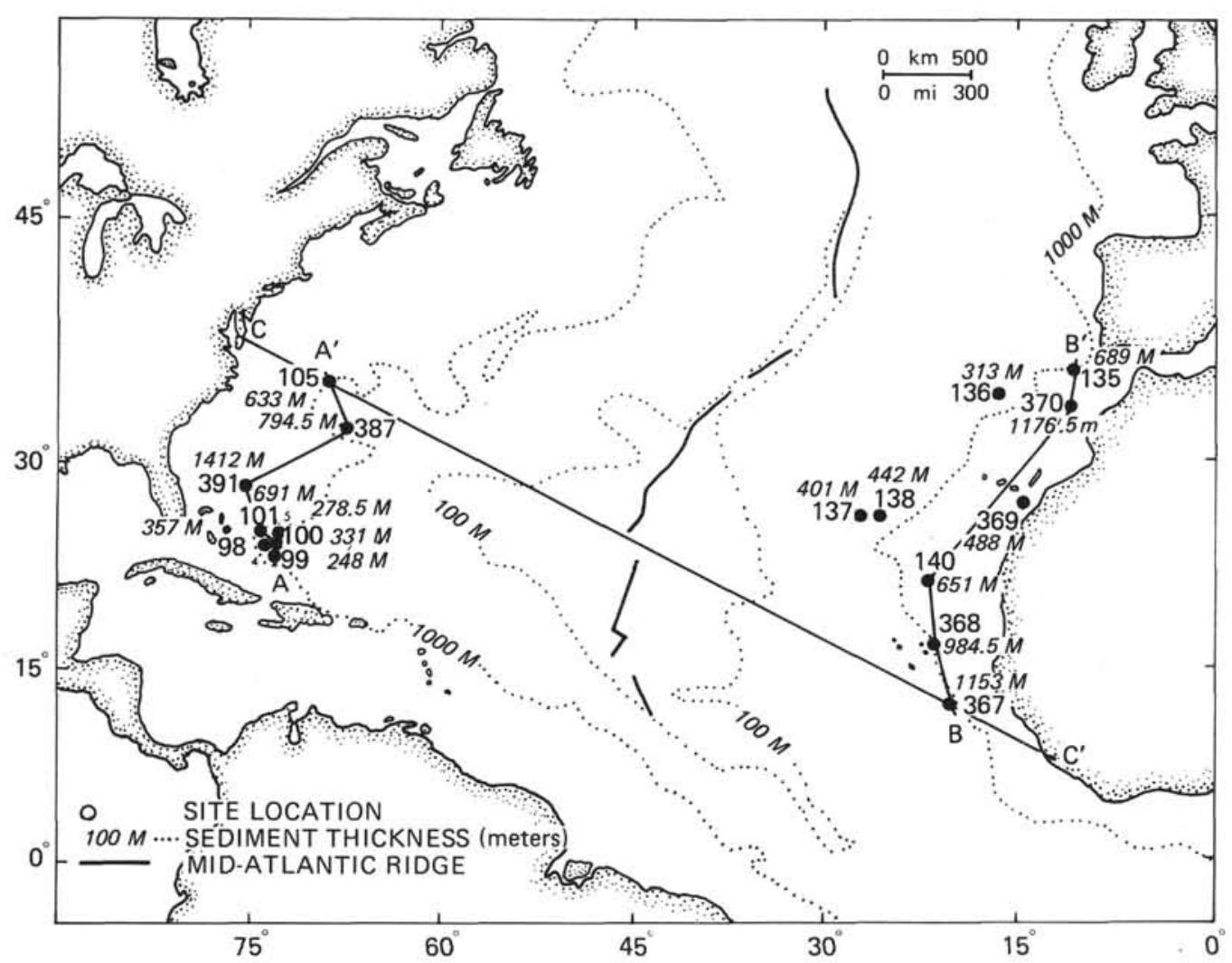

Figure 1. Subbottom penetration (in $m$ ) of the DSDP sites which penetrated into the Mesozoic in the central North Atlantic and location of the cross-sections, portrayed on Figures 3, 4, and 5. Site 387 from DSDP Leg 43 (Tucholke, Vogt, et al., 1975) and Site 391 from Leg 44 (Benson, Sheridan, et al., 1976) are used recognizing that the data are very preliminary.

The limestone overlying the basalt at Site 367 shows slightly higher induration but no sign of thermal metamorphism. The microfossils in this limestone are well preserved and not recrystallized (Plate 1, Figure 3). A thin pyroclastic zone at Site 105 occurs above fractured basalt, and a sharp contact between basalt and overlying sediments characterizes Site 100 (Lancelot et al., 1972) where some sediment and a bryozoan incorporated in the upper part of the basalt may indicate a pillow lava. Basalts at all three sites have feathery pyroxene-plagioclase intergrowth texture (Plate 1, Figure 2) which is typical of quenched basalts. Similar basalts have been dredged from the MidAtlantic Ridge (Bryan, 1972) and drilled during Leg 37 (Aumento et al., 1974), all interpreted by the authors as basalt flows.

The textural characteristics of basalts at Sites 367, 105 , and 100 and the character of their contacts with overlying sediments suggests they are flows, or nearsurface intrusions. According to the results of the seismic reflection studies these basalts correspond to the top of the acoustic basement, which can be followed throughout the eastern and western North Atlantic basins (Hollister et al., 1972; Lancelot et al., 1972; see Site Report Chapters, this volume). The top of the acoustic basement is correlated with the top of layer 2, which is assumed to be formed by volcanics interbedded with sediments. Drilling on the Mid-
Atlantic Ridge found volcanic rocks interbedded with minor amounts of sediment (Aumento et al., 1974).

\section{MESOZOIC LITHOSTRATIGRAPHY}

The stratigraphic methods used to delineate and correlate Mesozoic rock units in the central North Atlantic are the same as used in subsurface studies on continents. The parameters most useful for recognizing and correlating the North Atlantic Mesozoic sequences include major color changes and inorganic and organic constituents and their variations, especially as they affect the calcium carbonate, silica, and clay minerals content; bedding and bioturbation.

The Mesozoic of the central North Atlantic is subdivided into seven lithologic units (Table 1) some of which have been recognized by Lancelot et al. (1972). The lithology, age relationships, and depositional environments of these units are summarized in Table 1. The correlation of these units between the western and eastern North Atlantic and their schematic development parallel to the North American and Northwest African margins is portrayed in Figures 3, 4, and 5. The lithologic units are described in an ascending order.

\section{Greenish-gray Limestone Unit}

Relatively homogeneous greenish gray argillaceous limestone and marl with some brownish gray laminae 


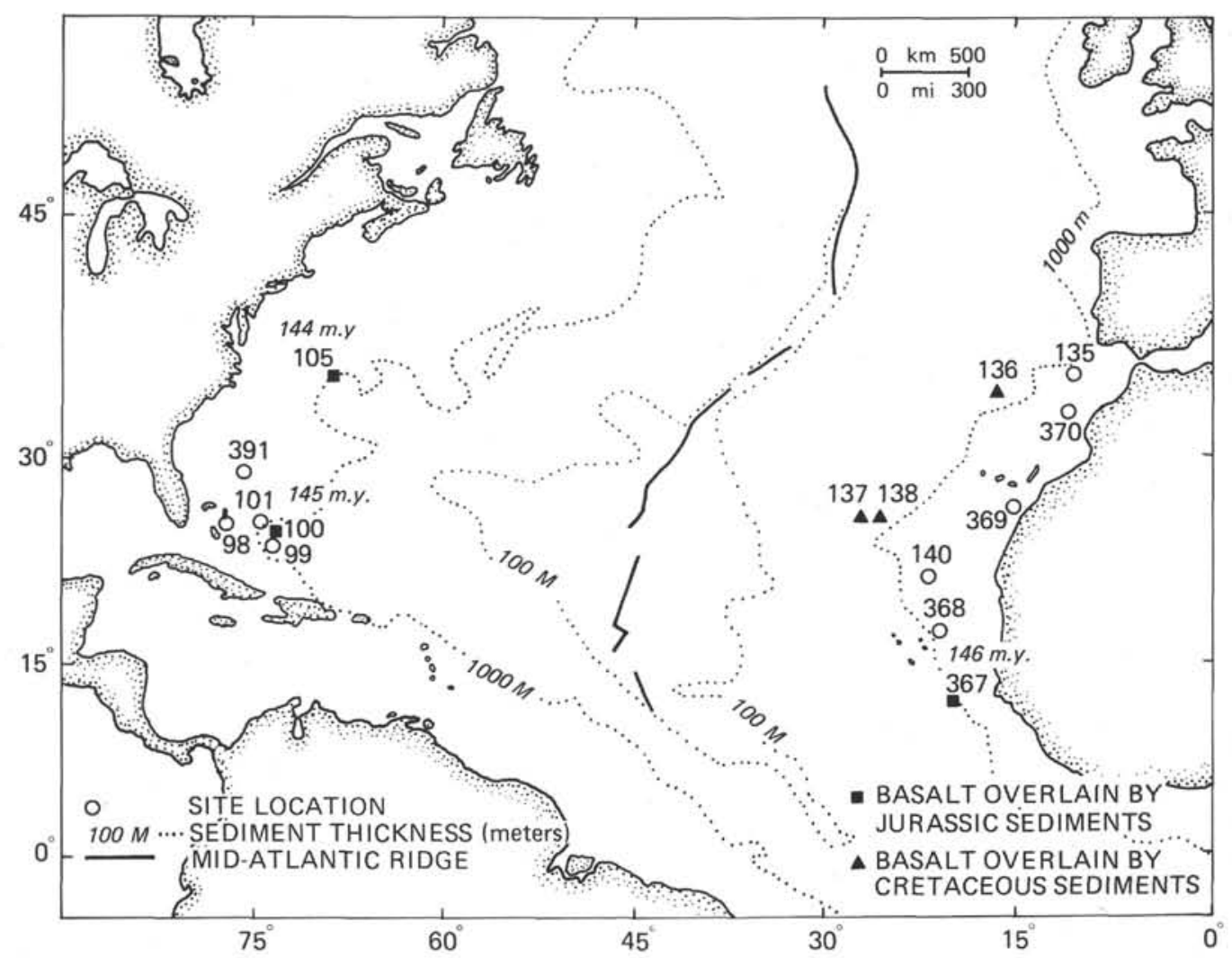

Figure 2. Location of DSDP sites which penetrated into basalts interpreted as a basement in the central North Atlantic which were overlain by Mesozoic rocks.

in the lower part of the sequence was penetrated at DSDP Site 100 (Cores 7 through 10, Section 2) (Table 2, Figure 6). The unit overlies basalt with a sharp contact. Laminations and some current bedding are present in the upper part of Core 7 and bioturbation is common (Hollister et al., 1972).

A similarly colored limestone also overlies basalt at Site 367 (Core 38, Figure 6). Only 50\% of the core was recovered at this site, and it is uncertain if the greenish limestone forms a separate unit or represents local thickening of the greenish beds which alternate with the reddish brown colored beds in the overlying unit. The composition of the basal greenish gray beds at Site 367 is different from the overlying sediments and thus it may represent a similar or transitional unit to the greenish gray limestone.

The sediments of the greenish gray limestone unit at Site 100 are comprised of euhedral calcite, variable amounts of montmorillonite, palygorskite, kaolinite, mica, K-feldspar, rare quartz, and silt size microfossils (Plate 1, Figure 5) (Zemmels et al., 1972), nannoplankton (Plate 2, Figure 1), and rare Radiolaria, the latter replaced by chalcedony. Pelagic bivalves which, in thin section, have the appearance of short "filaments," comparable with the pelagic bivalve Bositra of the Alpine Jurassic occur in Core 7. Additional macrofossils include minor echinoid fragments and planktonic crinoids of the genus Saccocoma. Arenaceous foraminifers, ostracodes, and aptychi are rare (Luterbacher, 1972). Common plant fragments and well-preserved dinoflagellates (Habib,
1972) are enclosed in the limestone. Occasionally thin laminae of silt size peloid grains (Plate 2, Figure 2) occur.

The limestone at Site 367 (Core 38, Section 1) is an argillaceous biomicrite (Plate 1, Figure 3 ) containing a variety of minute organic debris belonging to Globochaete, calcisphaerulids, the benthic foraminifers, proto-globigerinids, ostracodes, aptychi, and traces of fish debris (Plate 2, Figures 3, 4). The groundmass, consisting of dense, welded neomorphic calcite and clays, contains minor well-preserved nannofossils and quartz silt (Plate 2, Figure 1). Several flattened clasts of palagonite may represent altered volcanic glass fragments. A few small voids in the limestone are filled by authigenic chlorite. The limestone is nonporous with strongly, diagenetically altered groundmass.

\section{Depositional Environment}

Calcareous microfossils represented by nannoplankton, planktonic crinoids, and foraminifers indicate deposition in the pelagic realm. The presence of simple-structured foraminifers and dwarfed ostracodes at Site 100 is interpreted by Oertli (1972) and Luterbacher (1972) and at Site 367 by Kuznetsova and Seibold (this volume) as indicative of an upper bathyal environment. The plant debris, well-preserved dinoflagellates, kaolinite, and K-feldspars at Site 100 suggest the introduction of shallower water and continent-derived material into the bathyal environment, probably by turbidity currents. Deposition occurred well above carbonate 
TABLE 1

Stratigraphic Characteristics of the Lithozones Recognized in Southern North Atlantic

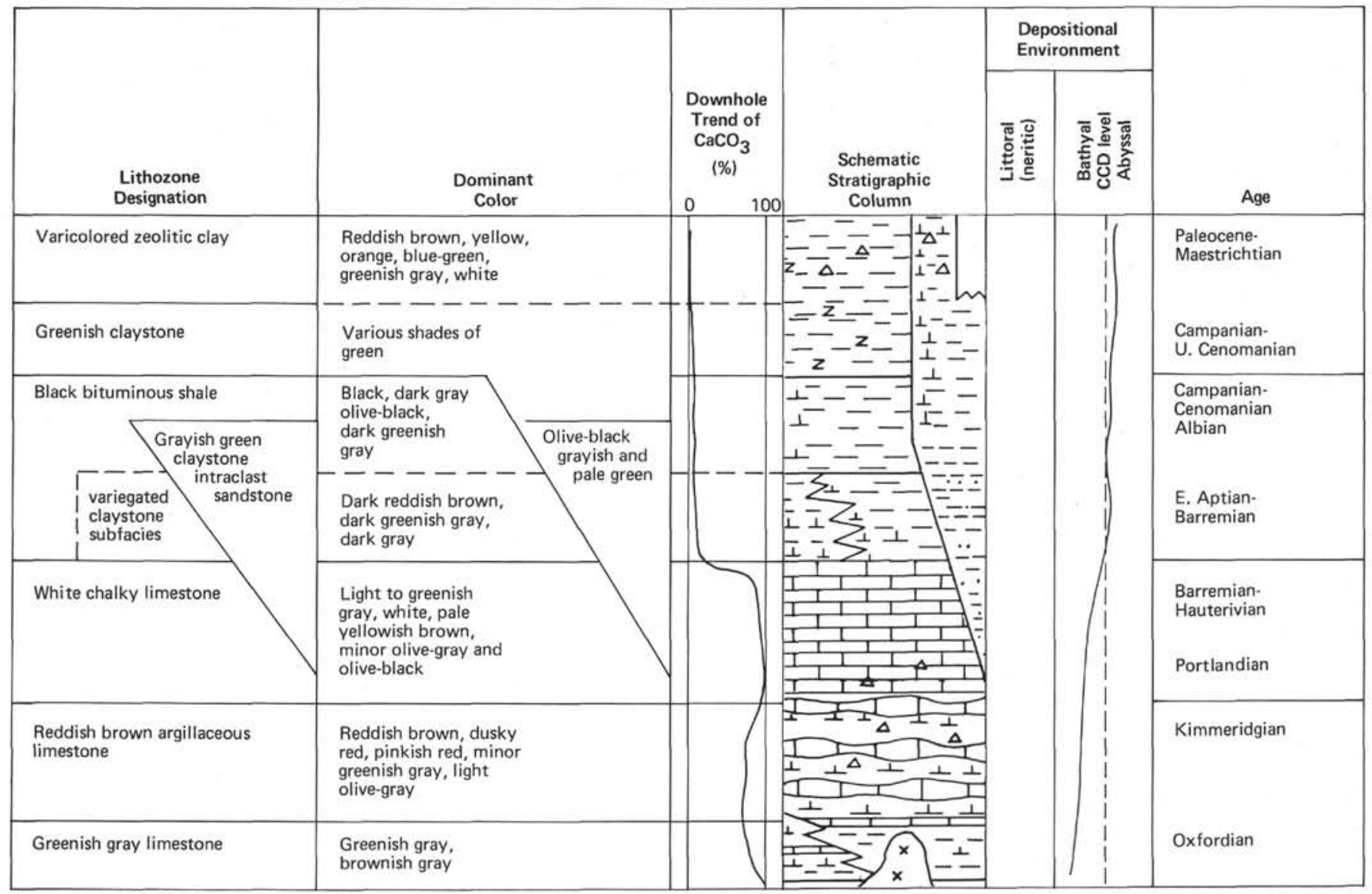

compensation depth (CCD), probably in an epibathyal environment.

\section{Age}

The greenish gray limestone unit at Site 100 is considered by Hollister et al. (1972) to be of Callovian age and thus to represent the oldest sediments recovered from the North Atlantic. The lowest two sedimentary cores ( 9 and 10) contain Oxfordian, Callovian, and Bathonian dinoflagellates (Habib, 1972). The calcareous nannoplankton in these cores are Oxfordian or Callovian (Hollister et al., 1972), but according to Thierstein (in Larson and Hilde, 1975) the nannoplankton may possibly be restricted to the Oxfordian. For the other microfossils the association of protoglobigerinids, Saccocoma, Globochaete, calcisphaerulids, and filaments is characteristic of the Oxfordian in the western Mediterranean Jurassic (Azema et al., 1974), and thus the upper age limit of the greenish gray limestone unit is considered to be most probably lower Oxfordian. The foraminiferal assemblage indicates an Oxfordian age (Seibold, this volume). An Oxfordian age is in better agreement with Upper Jurassic depositional rates, which are discussed later. Site 100 is located near the Keathley magnetic lineations and is placed by Larson and Hilde (1975) in the Jurassic quiet magnetic zone just older than anomaly M-25. Site 367 is also located inside the quiet magnetic zone in an area older than M-25 (Hayes and
Rabinowitz, 1975), which would confirm an Oxfordian age for Keathley lineation M-25, as has been suggested by Larson and Hilde (1975).

\section{Reddish Brown Argillaceous Limestone Unit}

Overlying the greenish gray limestone unit with a gradational contact are reddish brown and pinkish red argillaceous limestones, alternating with marlstones, calcareous shales, and sporadic chert nodules and bands. This unit was encountered at Sites 105, 100, and 99 in the southwest North Atlantic (Hollister et al., 1972), and at Site 367 in the eastern North Atlantic in the Cape Verde Basin (Table 3, Figure 7).

In the Cape Verde Basin the reddish brown and pinkish red argillaceous limestone is $\mathbf{3 3 . 5}$ meters thick,

LEGEND for Figs. 3,4 and 5.

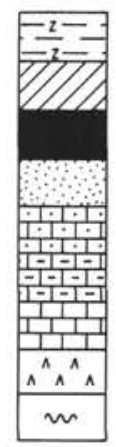

VARICOLORED ZEOLITIC CLAY LITHOZONE

GREENISH CLAYSTONE LITHOZONE

BLACK TO BITUMINOUS SHALE LITHOZONE

GRAYISH-GREEN CLAYSTONE-INTRACLAST SANDSTONE LITHOZONE

WHITE CHALKY LIMESTONE LITHOZONE

REDDISH-BROWN ARGILLACEOUS LIMESTONE LITHOZONE

GREENISH-GRAY LIMESTONE LITHOZONE

OCEANIC BASEMENT

UNCONFORMITY 
A

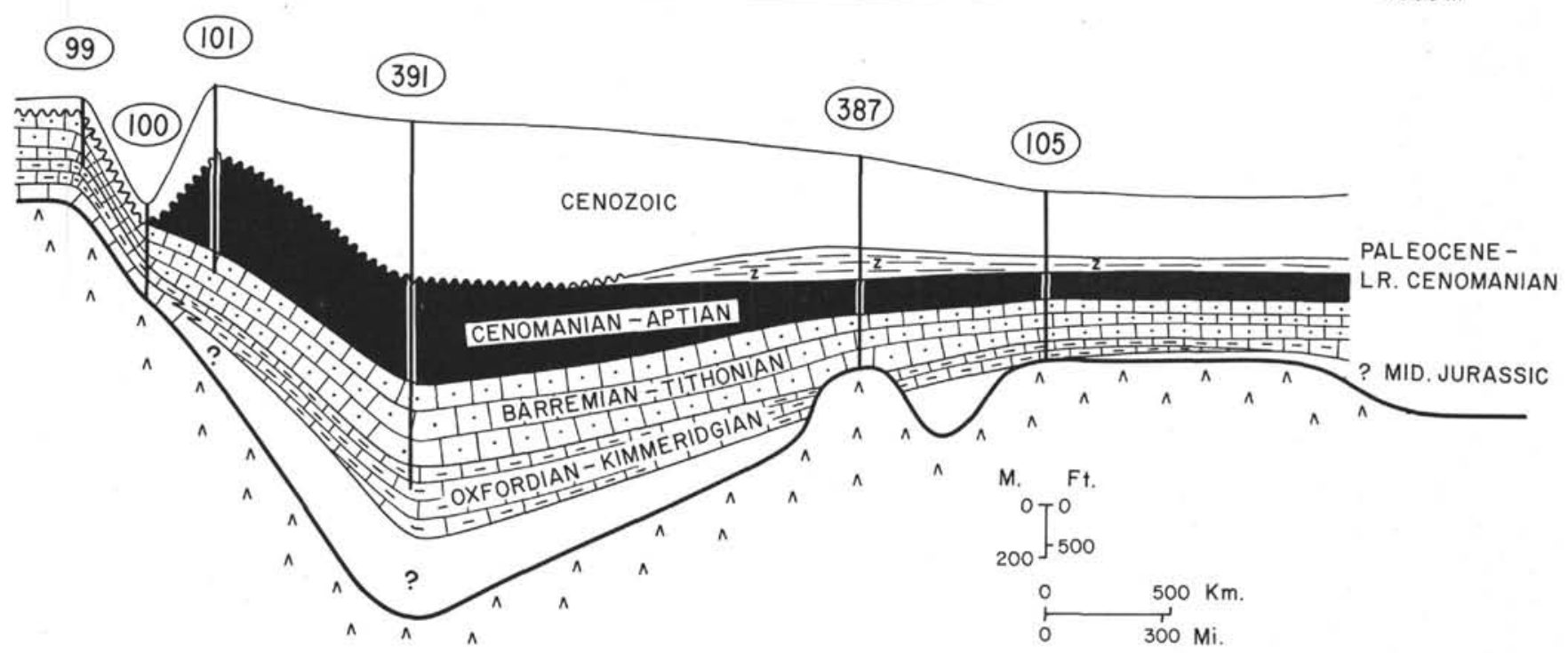

Figure 3. Schematic lithostratigraphic cross-section parallel with the North American continental margin in western North Atlantic (for the location see Figure 1). Site 387 from DSDP Leg 43 (Tucholke, Vogt, et al., 1975) and Site 391 from Leg 44 (Benson, Sheridan, et al., 1976) are used recognizing that the data are very preliminary.

B
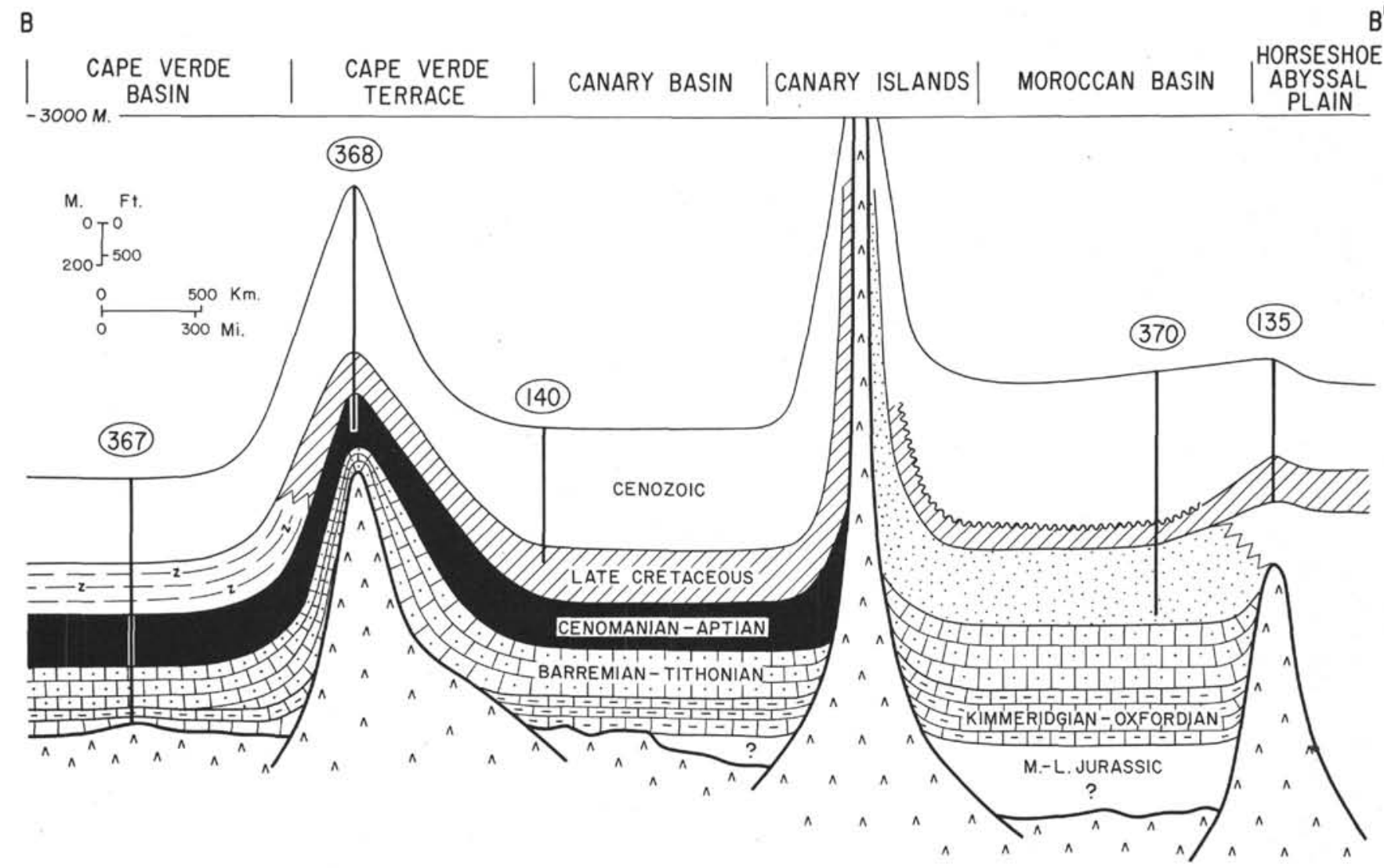

Figure 4. Schematic lithostratigraphic cross-section parallel with the northwestern African continental margin in the eastern North.Atlantic (for the location see Figure 1). 


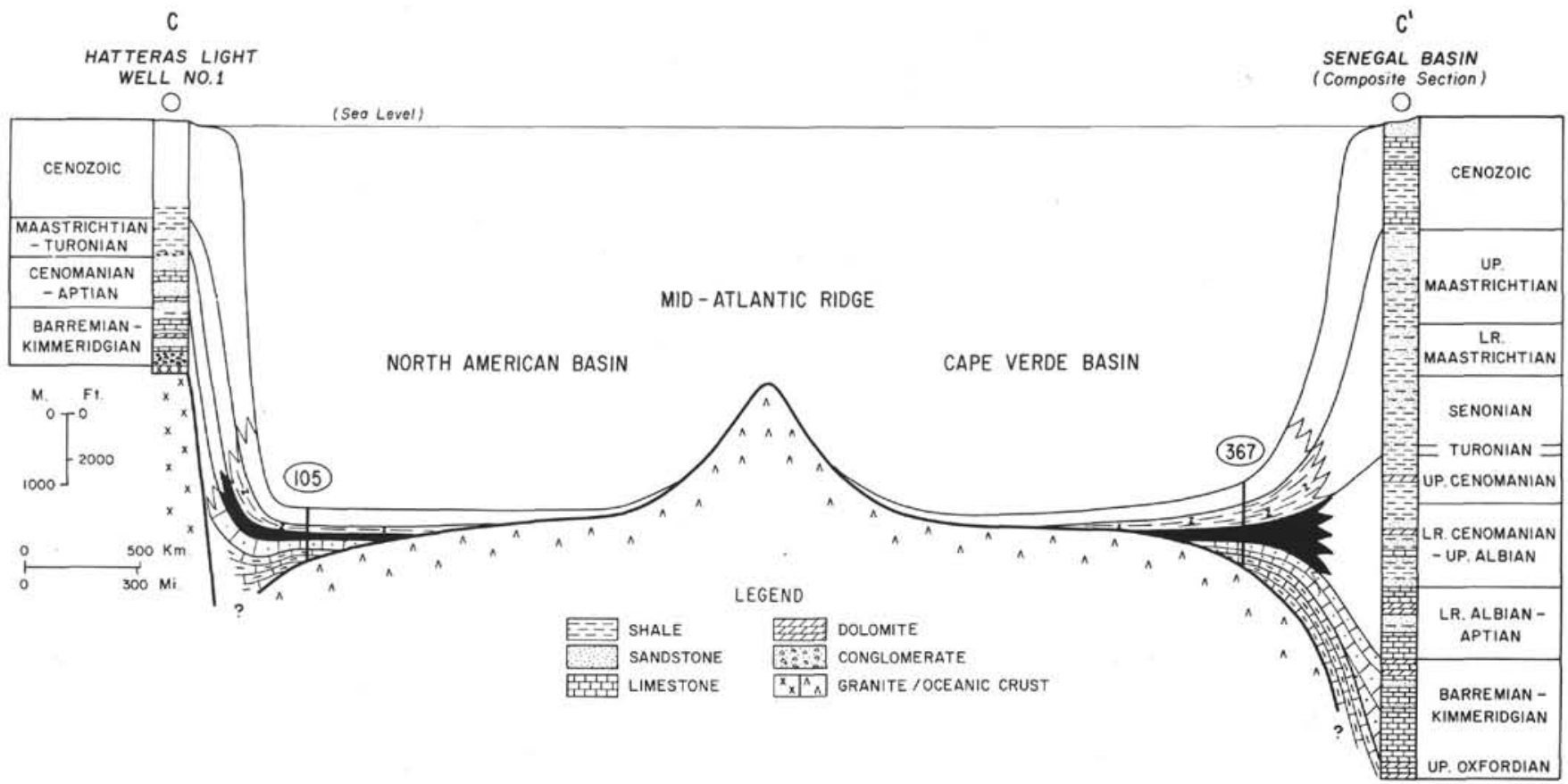

Figure 5. Schematic lithostratigraphic cross-section from Sengal Basin to Cape Hatteras light well no. 1 across central North Atlantic (for the location see Figure 1).

TABLE 2

Greenish Gray Limestone Unit Occurrences in Central North America

\begin{tabular}{|c|c|c|c|c|}
\hline Region & DSDP Site & Core & $\begin{array}{c}\text { Subsea } \\
\text { Depth } \\
\text { (thickness) } \\
(\mathrm{m})\end{array}$ & Age \\
\hline Blake-Bahama & 100 & $\begin{array}{c}7-10 \\
\text { Section } 2\end{array}$ & $-5611(29)$ & $\begin{array}{c}\text { Oxfor- } \\
\text { dian }\end{array}$ \\
\hline Cape Verce & 367 & $\begin{array}{c}? 38 \\
\text { (transi- } \\
\text { tional } \\
\text { zone) }\end{array}$ & $-5890(2)$ & $\begin{array}{c}\text { Oxfor- } \\
\text { dian }\end{array}$ \\
\hline
\end{tabular}

locally nodular, interbedded with marls (Plate 1, Figure 4), calcareous clays, and minor chert nodules and bands. In the lower 18 meters of the sequence the limestone alternates with greenish gray and light olivegray limestone and claystone beds, which may indicate downward transition into the greenish gray limestone lithozone. Limestone of the reddish brown argillaceous limestone unit is variably argillaceous with its clay mineral content increasing slightly toward the base of the unit. Red hematite stains intensify with increasing clay content in the limestone, which makes it apparent that the coloration is associated with clay minerals. A variety of sedimentary features is displayed in the sediments. Fine laminae, regular and wavy (Plate 1, Figure 4) caused by higher concentration of clay, are common. The occurrence of low-angle cross-bedding, calcareous silt beds with both boundaries sharp, and breccia beds all suggest intermittent current activity at the sea bottom and occasional turbidite deposition. Boudinage leading to the development of nodular texture in some of the beds is a secondary diagenetic feature. For the first time, well-developed stylolites were observed in sediments recovered from the deep ocean in this unit.

Variations in composition and microfossil assemblages enable subdivision of the reddish brown argillaceous limestone unit at Site 367 into three distinctive microfacies-the Radiolaria, filaments, and Saccocoma microfacies which were also recognized at Sites 105 and 100 . The names of the microfacies are derived from the characteristic microfossils present.

\section{Radiolarian Microfacies (Site 367, Core 37, thickness $7 \mathrm{~m}$ )}

The radiolarian microfacies which overlies the greenish gray limestone at Site 367 is represented by highly argillaceous radiolarian packstone to wackestone (Plate 2, Figure 6) composed of radiolarian molds filled by chalcedony (Plate 2, Figure 5) and/or by calcite, calcisphaerulids, and rare foraminifers. Among macrofossils, aptychi, sponge spicules, and echinoderm debris occur occasionally. The matrix is neomorphic micrite, with a particle size of $5 \mu \mathrm{m}$, containing moderately preserved nannoplankton and clay minerals, the latter stained red by iron oxide. Despite the large component of biogenic silica in this microfacies, it lacks development of chert and porcellanite, possibly due to the high clay mineral content, the low permeability of the sediment, and the unavailability of extra silica ions other than those supplied by dissolution of radiolarian tests. The contact of the radiolarian microfacies with the overlying filament microfacies is transitional and the boundary is rather arbitrary.

Filament Microfacies (Site 367, Cores 36-35, Section 3, thickness $13.5 \mathrm{~m}$ )

The name of this microfacies is derived from the presence and local concentration of remnants of pelagic 


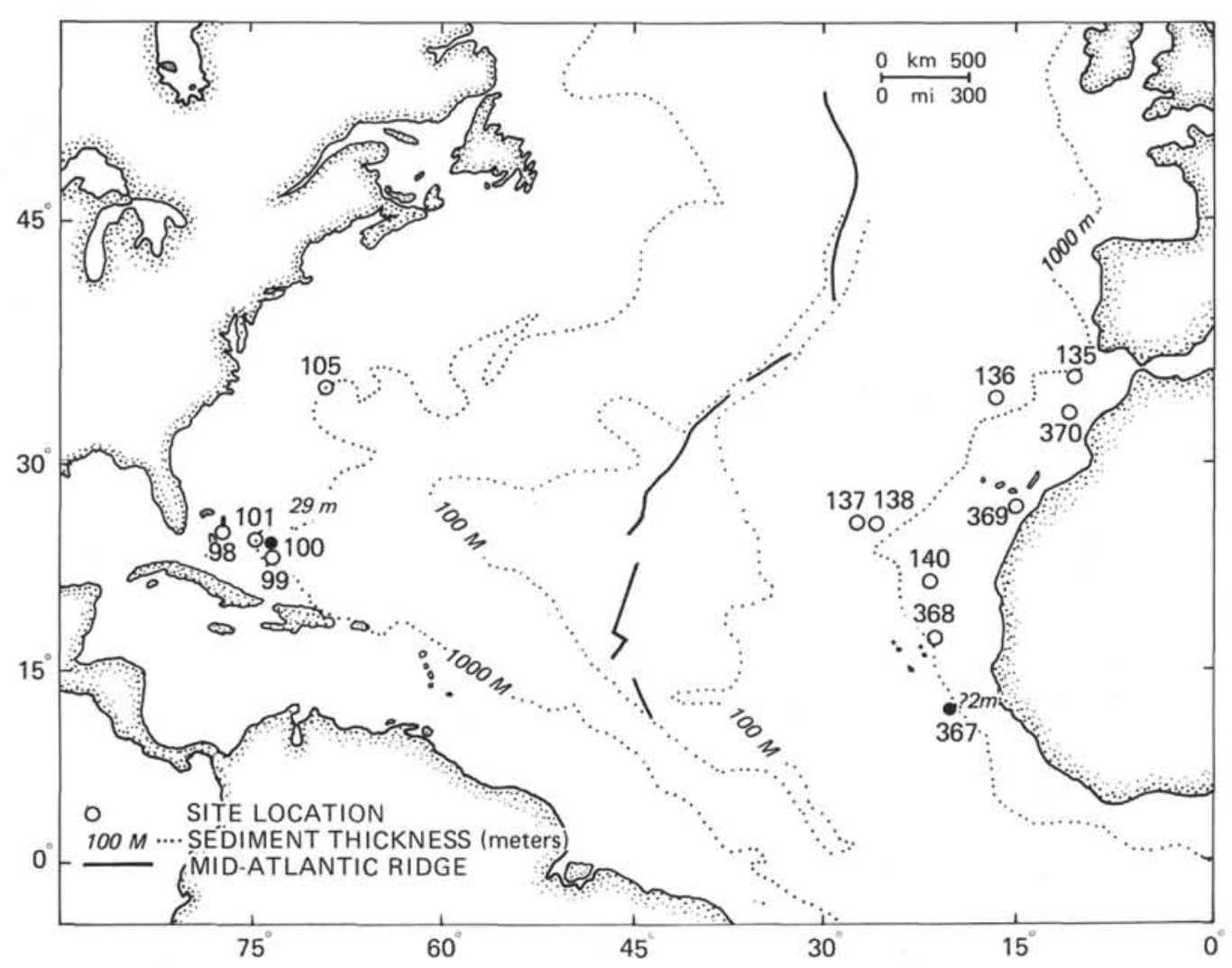

Figure 6. Occurrences and thickness of the Oxfordian greenish gray limestone unit in the central North Atlantic. Dark circle represents a site where this unit occurs.

TABLE 3

Reddish Brown Argillaceous Limestone Unit Occurrences in the Central North Atlantic

\begin{tabular}{|c|c|c|c|c|}
\hline Region & DSDP Site & Core & $\begin{array}{l}\text { Subsea } \\
\text { Depth } \\
\text { (thick- } \\
\text { ness) } \\
\text { (m) }\end{array}$ & Age \\
\hline Cape Verde & 367 & $\begin{array}{c}32, \\
\text { Sections 5-37 }\end{array}$ & $\begin{array}{c}-5895.5 \\
(33.5)\end{array}$ & $\begin{array}{l}\text { Kimmerid- } \\
\text { gian } \\
\text { Oxfordian }\end{array}$ \\
\hline $\begin{array}{l}\text { Hatteras } \\
\text { Abyssal }\end{array}$ & 105 & $\begin{array}{l}\quad 33 \\
\text { Sections 2-40 } \\
\text { Section } 1\end{array}$ & $\begin{array}{c}-5893 \\
(70)\end{array}$ & $\begin{array}{l}\text { Kimmerid- } \\
\text { gian } \\
\text { Oxfordian }\end{array}$ \\
\hline $\begin{array}{l}\text { Blake- } \\
\text { Bahama } \\
\text { Basin }\end{array}$ & 100 & $2-6$ & $\begin{array}{c}-5572 \\
(89)\end{array}$ & $\begin{array}{l}\text { Kimmerid } \\
\text { gian- } \\
\text { Oxfordian }\end{array}$ \\
\hline $\begin{array}{l}\text { Blake- } \\
\text { Bahama } \\
\text { Basin }\end{array}$ & $99 \mathrm{~A}$ & $12-14$ & $\begin{array}{l}-5159 \\
(13)\end{array}$ & $\begin{array}{l}\text { Kimmerid- } \\
\text { gian } \\
\text { Oxfordian }\end{array}$ \\
\hline
\end{tabular}

bivalves, which in the European Jurassic are commonly related to the genus Bositra (Kuhry, 1975). This pelecypod is considered to be an epifaunal suspension feeder that lived probably attached to floating objects-most likely algal fronds (Duff, 1975). This characteristic could account for the occasionally high concentrations of the fragile tests in the sediments. The inner aragonitic valve of the shells was dissolved and only the outer filament-like thin valve was preserved (Jefferies and Minton, 1965).
The filaments in the limestone of Site 367 are either dispersed in the micritic matrix or concentrated into thin laminae and lenses. In some samples filaments show an imbricated fabric which indicates reworking by bottom currents. Filaments are also concentrated by bioturbation as suggested by the swirl patterns. Syntaxial calcite overgrowth is common (Plate 3, Figure 3). Other, rare, macrofossils are aptychi and occasionally Saccocoma. Microorganisms present are nannoplankton, calcisphaerulids, and rare foraminifers and Radiolaria.

The matrix of the limestone is neomorphic micrite (Plate 3, Figure 2) with variable admixture of hematite stained clays. Strong diagenetic alteration lead to nannofossil replacement and destruction of the primary porosity in limestones with low argillaceous content. In limestones with high argillaceous content (Plate 4, Figure 3), the diagenetic alteration is lower and the nannofossils are better preserved. In general, the intensity of diagenesis decreases upward in the sequence (compare Plate 4, Figure 3 and Plate 5, Figure 1).

Near the lower boundary of the filament microfacies (Core 36, Section 3), radiolarian packstone alternates with filament-radiolarian wackestone laminae (Plate 3, Figure 1). The boundaries between laminae are sharp. Filaments are broken (Plate 3, Figure 5) which, together with the presence of rare quartz silt grains, may indicate that the pelecypods were redeposited from a shallower environment. Rare chert and porcellanite nodules occur in the upper part of the filament 


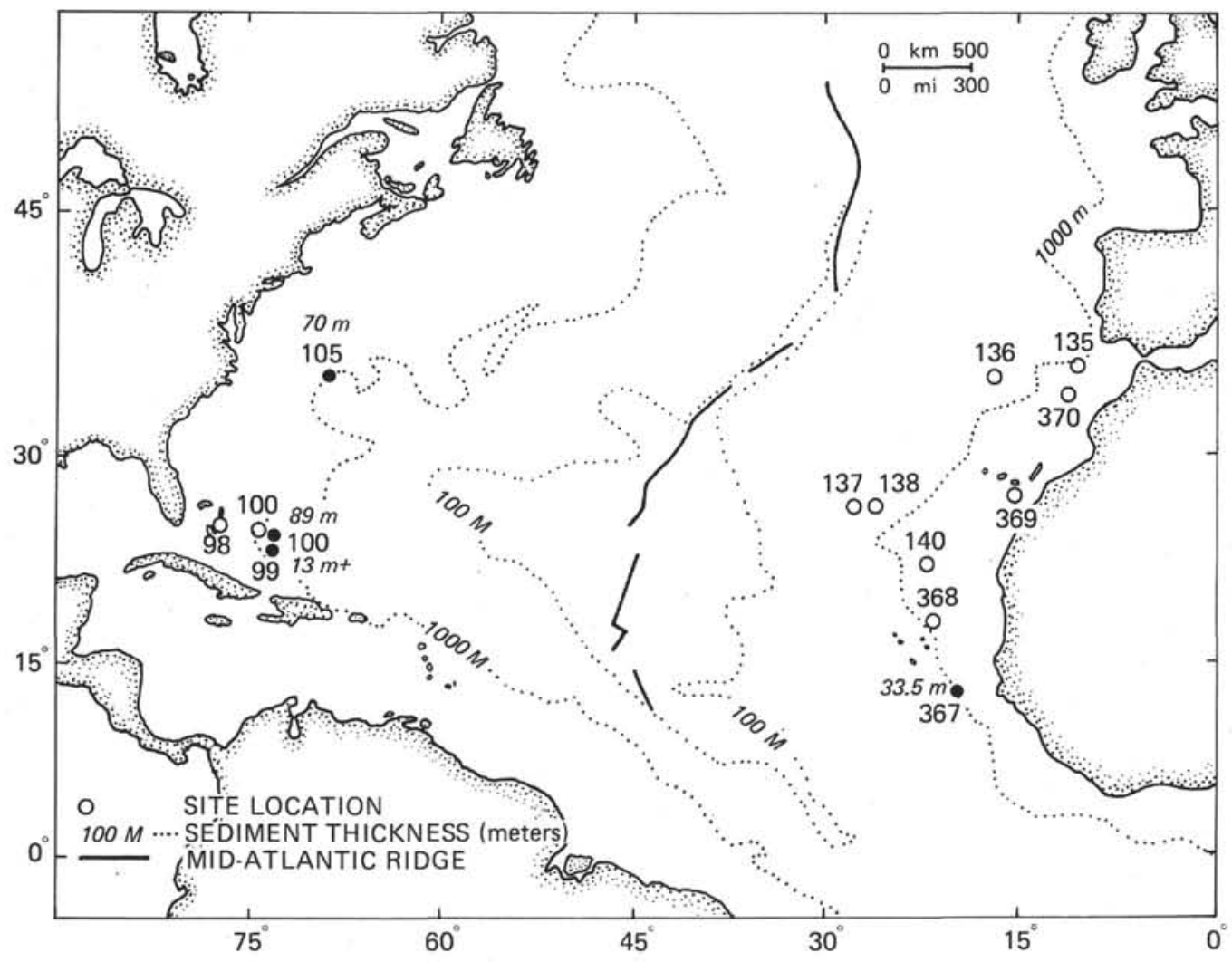

Figure 7. Occurrences and thickness of the reddish brown argillaceous limestone unit in the central North Atlantic. Dark circle represents a site where this unit occurs.

microfacies. The boundary with the overlying microfacies is relatively sharp, but there is no macroscopic difference between these subunits.

\section{Saccocoma Microfacies (Site 367, Core 35, Sections 2-} 32, Section 5; thickness $33 \mathrm{~m}$ )

This microfacies is an argillaceous nannofossilbearing biomicrite characterized by the presence of numerous fragments of the planktonic crinoid Saccocoma (Plate 4, Figure 2) which usually occur as fine silt to fine sand-size particles, frequently with syntaxial calcite overgrowth. Less common to rare are filaments and aptychi. Among microfossils radiolarian molds filled by chalcedony and/or by calcite are rare to abundant, and foraminifers and calcisphaerulids are rare. The matrix of the limestone is a mixture of micrite and argillaceous minerals stained red by iron oxide. The presence of rare skeletal packstone laminae with fine to coarse silt-size skeletal fragments (Plate 4, Figure 2) indicates sluggish bottom currents and local reworking of deposited sediments. Chert nodules and porcellanite are very common on the lower part of the microfacies. The top of the Saccocoma microfacies at Site 367 coincides with the top of the reddish brown limestone unit. The contact of the Saccocoma microfacies with the overlying light gray nannofossil limestone is sharp.

In the western North Atlantic at Site 105 the reddish brown argillaceous limestone lithozone directly overlies basalt (Cores 33-39, Hollister et al., 1972). Hollister et al. (1972) placed the upper boundary of the reddish limestone sequence between Cores 33 and 32 , but the changes in the microfossil association, density, and color of the limestone all indicate that the boundary should be placed at the top of Core 33, Section 2. The color change from the reddish brown argillaceous limestone unit to the overlying sequence at Site 105 is not as sharp as in the Cape Verde Basin.

The limestone at Site 105 is reddish brown to pale red with rare green zones and bands. Redeposition in the limestones appears more frequently than was observed in the Cape Verde Basin, which may relate to the rugged basement topography in the vicinity of Site 105 (Lancelot et al., 1972). The redeposited beds range from slumps to graded siltstones and homogeneous mudstones, and exhibit cyclic development. The disturbed zones are covered by homogeneous or faintly laminated red and gray marls. In the upper part of the lithozone contemporaneously displaced intraclasts and lumps of white indurated limestone contain protoglobigerinids and small calcite replaced Ammonites (Hollister et al., 1972; Bernoulli, 1972). According to Luterbacher (1972), protoglobigerinids are not present elsewhere in the sequence, which suggests that the white limestone was deposited on a topographic high above the carbonate compensation depth (CCD) for planktonic foraminifers, and was later displaced by slumps or turbidity currents. The presence of calcareous benthic foraminifers (lagenids) in the reddish limestone, on the other hand, precludes deposition of this limestone below the CCD. Other microfossils recognized in the reddish brown limestone are nannoplankton (Plate 5, Figure 2), radiolarians, and calcisphaerulids. Macrofossils include pelagic 
bivalves (filaments), Saccocoma, echinoderm fragments, aptychi, and fish debris (Luterbacher, 1972). The matrix of the limestone is a highly variable mixture of neomorphic micrite and clay minerals stained by iron oxide (Plate 5, Figure 2). Sediments of the reddish brown limestone unit at Site 105 have a lower degree of diagenetic lithification and they are more argillaceous than those in the Cape Verde Basin.

The reddish-brown argillaceous limestone unit at Site 105 can be tentatively subdivided into the filament microfacies (Cores 37-39) and the Saccocoma microfacies (Core 33, Sections 2-36). The radiolarian microfacies, which is the oldest microfacies in the Cape Verde Basin (Site 367), is absent. The filament microfacies at Site 105, which directly overlies basalt, is a variably argillaceous biomicrite with a groundmass composed of neomorphic calcite and argillaceous matter (Plate 5, Figure 2) stained reddish by iron oxide. It contains nannofossils, pelagic bivalves, foraminifers, ostracodes, aptychi, radiolarian casts, rare Saccocoma, fish fragments, and in the upper part of the microfacies rare calcisphaerulids (Plate 3, Figure 6). The Saccocoma microfacies (Plate 4, Figure 4) is similar to the underlying filaments microfacies, from which it differs by the occurrence of pelagic crinoids Saccocoma, and the rarity or absence of filaments. Radiolaria casts filled by silica are common. Juvenile Ammonites casts are present in Core 35.

In the Cat Gap area similar reddish brown marls and limestones were penetrated at two sites (100 and 99A, Hollister et al., 1972). At Site 99A core recovery was extremely poor; reddish marl alternates with white and greenish limestone and marl, with the greenish bands rich in carbonaceous matter and plant debris. At Site 100 , reddish and some greenish gray and light gray marl alternates with slightly nodular argillaceous limestone. The upper part of the unit contains chert and porcellanite. Marl is slightly bioturbated and chondrites trace fossils were recognized in the sequence. Faint lamination, in places wavy, is common. Lithifield mud pebbles, white limestone clasts, and slump features near the top of the unit indicate redeposition and penecontemporaneous displacement of pelagic sediments similar to Site 105 . Slumping could be related to the location of the site near the sloping flank of a basement high which can be seen on a seismic profile across the site (Hollister et al., 1972).

The sediments of the reddish-brown argillaceous limestone unit at Site 100 are composed of a highly variable mixture of clay minerals dominated by palygorskite and montmorillonite (Zemmels et al., 1972), and of carbonates with $\mathrm{CaCO}_{3}$ content variable from $95 \%$ to $17 \%$ (Boyce, 1972). The dominant component of the limestone is neomorphic calcite with nannoplankton and rare silica and/or calcite-filled molds of radiolarians, calcisphaerulids, and Globochaete. Macrofossils include fragments of the planktonic crinoid Saccocoma, which are abundant in Cores 4 and 2 (Plate 4, Figure 5) and are present in all other cores of the unit, and aptychi and echinoderm fragments. Short filaments with sparry calcite overgrowths (Plate 3, Figure 4) are mixed with fragments of Saccocoma in Core 4, Section 1. The poor benthic assemblage consists of primitive agglutinated foraminifers and deep water ostracodes (Luterbacher, 1972).

The separation into microfacies at Site 100 is less distinctive than at Site 367 , and probably only the Saccocoma microfacies is present. The presence of rare filaments in the underlying greenish-gray limestone lithozone may indicate that the latter unit at Site 100 is at least in part the facies equivalent of the filaments microfacies of the reddish-brown argillaceous limestone unit, the principal difference being in color. This observation is significant for the interpretation of the age of the greenish gray limestone unit and supports Thierstein's (in Larson, Hilde, 1975) age interpretation of the nannoplankton from Site 100.

The contact of the reddish brown argillaceous limestone unit with the overlying sedimentary sequence at Sites 99 and 100 was not cored and remains unknown.

\section{Environment of Deposition}

The depositional environment of the reddish brown argillaceous limestone unit can be interpreted mainly from the fossil assemblage and their preservation, rather than from the sediment composition and texture. The restricted terrigenous influx of fine quartz silt, mica, and clay minerals seems to be related to distant sources and trapping of the clastics on the shelves. The presence of redeposited pelagic sediments suggest irregular submarine topography with local basins and highs (Lancelot et al., 1972). Sediment contains relatively diverse faunal assemblage; some of the groups are impoverished, for example, the foraminifers. Aptychi are relatively common, but the Ammonite phragmocones or even casts of Ammonite shells are exceptionally rare. This indicates that the sediment was deposited below the aragonite compensation depth. The influence of dissolution can also be seen in the distribution of planktonic foraminifers. Only rare protoglobigerinids were found in the reddish-brown argillaceous limestone unit (Sites 105 and 367), but the protoglobigerinids are very common in a shallower water Oxfordian limestone dredged at a depth of 3300 meters on the Moroccan continental slope (Renz et al., 1975).

The sediments of the reddish brown argillaceous limestone unit are interpreted to have been deposited above carbonate compensation depth which in recent oceans is between 4000 and 5000 meters, but below the aragonite compensation depth, which presumably varies between 1000 to 3000 meters (Bosellini and Winterer, 1975).

\section{Age}

The stratigraphic age of the reddish brown argillaceous limestone unit has been broadly interpreted to span the Kimmeridgian-Oxfordian (Hollister et al., 1972; Lancelot et al., this volume; Kuznetsova and Seibold, this volume). The sedimentary rocks enclosing the genus Saccocoma in the Mediterranean region are generally assigned to the Kimmeridgian (Azema et al., 1974; Lehman, 1972). Recognition of the lateral continuity of the above discussed microfacies in the 
central North Atlantic Mesozoic make it possible to indicate a Kimmeridgian age for the Saccocoma microfacies-however, Seibold (this volume) suggests Oxfordian age for Core 34-4-and an Oxfordian age for the filament microfacies.

The sediments of reddish brown argillaceous limestone unit were compared by Bernoulli (1972) with the Alpine Ammonitico Rosso facies, although in the Alpine-Mediterranean Jurassic various types of pelagic sediments are called Ammonitico Rosso. Originally the term was used for the red nodular limestone, rich in Ammonites, of Middle and Upper Jurassic age, outcropping in the region of Verona. The Ammonitico Rosso Veronese spans from topmost Bajocian to lower Tithonian (Assereto et al., 1975), and is characterized by the development of hard grounds, condensed stratigraphic sequences, dissolution features, ferromanganese encrustations and hiatuses, all typical of pelagic deposition over topographic highs-the swell facies. Another type of "Ammonitico Rosso" is represented by the thicker Toarcian to Aalenian marly facies exposed in the eastern Alps, central Apennines and western Greece and known as Rosso ad Aptici (Aubouin, 1964). These marls represent basinal facies, as also indicated by the abundance of the turbidites and slumps (Bernoulli and Jenkyns, 1974). The Ammonitico Rosso, although common in the Jurassic system, may extend into the Cretaceous, as for example in the Subbetic Cordillera, where it spans from Bajocian to lower Berriasian (Kuhry, 1972; Dabrio et al., 1971).

The reddish brown argillaceous limestone unit in the southern North Atlantic is characterized by the presence of argillaceous limestones, marls and clays, Ammonite aptychi, and by the lack or very rare occurrence of Ammonites phragmocones, and thus best corresponds to the marly Rosso ad Aptici facies of the Alpine Jurassic. The unit is considerably different from the swell facies, of the Ammonitico Rosso of the Mediterranean region.

\section{Depositional Rates and Age of the Basement}

A calculation based on depositional rates was used for another estimate of the age of the "basement" and of overlying sediments. Two assumptions have been made. First, that the sharp upper boundary of the reddish brown argillaceous limestone unit is contemporaneous on both sides of the central North Atlantic basin, representing perhaps a lacuna and thus is considered to be a time level and second, that the Saccocoma microfacies corresponds to the Kimmeridgian. The thickness of the Saccocoma microfacies, was used to calculate a depositional rate, which was then projected to basement. Using van Hinte's time scale for the Jurassic (Berggren et al., 1975), the Kimmeridgian spans from 138 to 143 m.y., and the Oxfordian from 143 to 149 m.y. Accordingly, the depositional rate of the Saccocoma microfacies in the Cape Verde basin is 6 to $7 \mathrm{~m} / \mathrm{m}$.y., giving an extrapolated age for the basalt at Site 367 of approximately $146 \mathrm{~m} . y$. (middle Oxfordian). In the western North Atlantic at Site 105 the depositional rate of the Saccocoma microfacies is $10.5 \mathrm{~m} / \mathrm{m} . \mathrm{y}$. , and the projected age of the basalt is about 144 m.y. In the Cat Gap area Site 100 has the highest depositional rate for the Kimmeridgian of $12 \mathrm{~m} / \mathrm{m}$.y., and the calculated age of the basalt (or of the oldest sediments just overlying the basalt) is 145 m.y.

\section{White Chalky Limestone Unit}

The white chalky limestone was penetrated by seven DSDP holes in the southern North Atlantic (Figure 8, Table 4) and a comparable sequence outcrops on Maio Island in the Cape Verde Archipelago (Stahlecker, 1934).

The sediments of this unit are white to greenish gray and sometimes pale yellowish brown, well-bedded soft chalks and chalky limestones occasionally alternating with thin beds of olive-gray to olive-black organic-rich marl (Plate 6, Figures 1, 2). The latter occur more frequently toward the top of the unit, but are rare to absent in the lower half of the sequence. The limestone is soft, homogeneous, and intensively bioturbated. The burrows are irregular and some of them can be compared with the Chondrites trace fossil.

Sporadic chert nodules and porcellanite bands are found in the lower part of the lithozone in the Cape Verde Basin (Plate 6, Figure 3) and in the Cat Gap area (Hollister et al., 1972). The dark gray finely-laminated (Plate 6, Figure 2) marl, which is interbedded with limestone, usually has a sharp or only slightly diffuse contact with the surrounding light gray limestone (Plate 6 , Figures 1,2). The carbonate content of the sequence is high, varying from $60 \%$ to $96 \% \mathrm{CaCO}_{3}$. The limestone is composed almost entirely of neomorphic micrite and calcareous nannoplankton (Plate 5, Figures 3,5 ) and always contains radiolarian casts replaced by sparry calcite and to a lesser extent by chalcedony (Plate 7, Figure 1). Occasionally the radiolarian tests are coated with pyrite (Plate 7, Figure 2). The presence of calpionellids near the base of the lithozone at Site 105 (Core 33, Section 1) (Plate 6, Figure 15), which were identified as belonging to the species Calpionella alpina Lorenz and Tintinopsella carpathica (Murgeanu and Filipescu) by Lehman (1972) and at Site 367 (Core 32, Section 5) identified as Calpionella alpina sp. (Plate 6, Figures 3,4 ) by the author, is characteristic. Higher up in the unit calpionellids are rare, poorly preserved, and recrystallized. Calcisphaerulids are always present (Plate 5, Figure 4) and nannoconids are frequent in some of the cores (Lehman, 1972; Cepek, this volume). Small planktonic foraminifers associated with the arenaceous foraminifers are rare and commonly absent (Luterbacher, 1972). Aptychi are relatively common and echinoderm, mollusk, and ostracode debris occur occasionally. The aptychi and nannoplankton are better preserved in the marl due to lower diagenetic alteration and recrystallization of the skeletal carbonate. The intensity of diagenetic alteration further decreases upwards in the sequence (see Plate 5, Figure $5)$. Some of the nannofossil-rich limestone beds have good interskeletal porosity (Plate 5, Figures 3, 5, 6).

The terrigenous component of the marls is dominated by clay minerals. Montmorillonite, illite, 


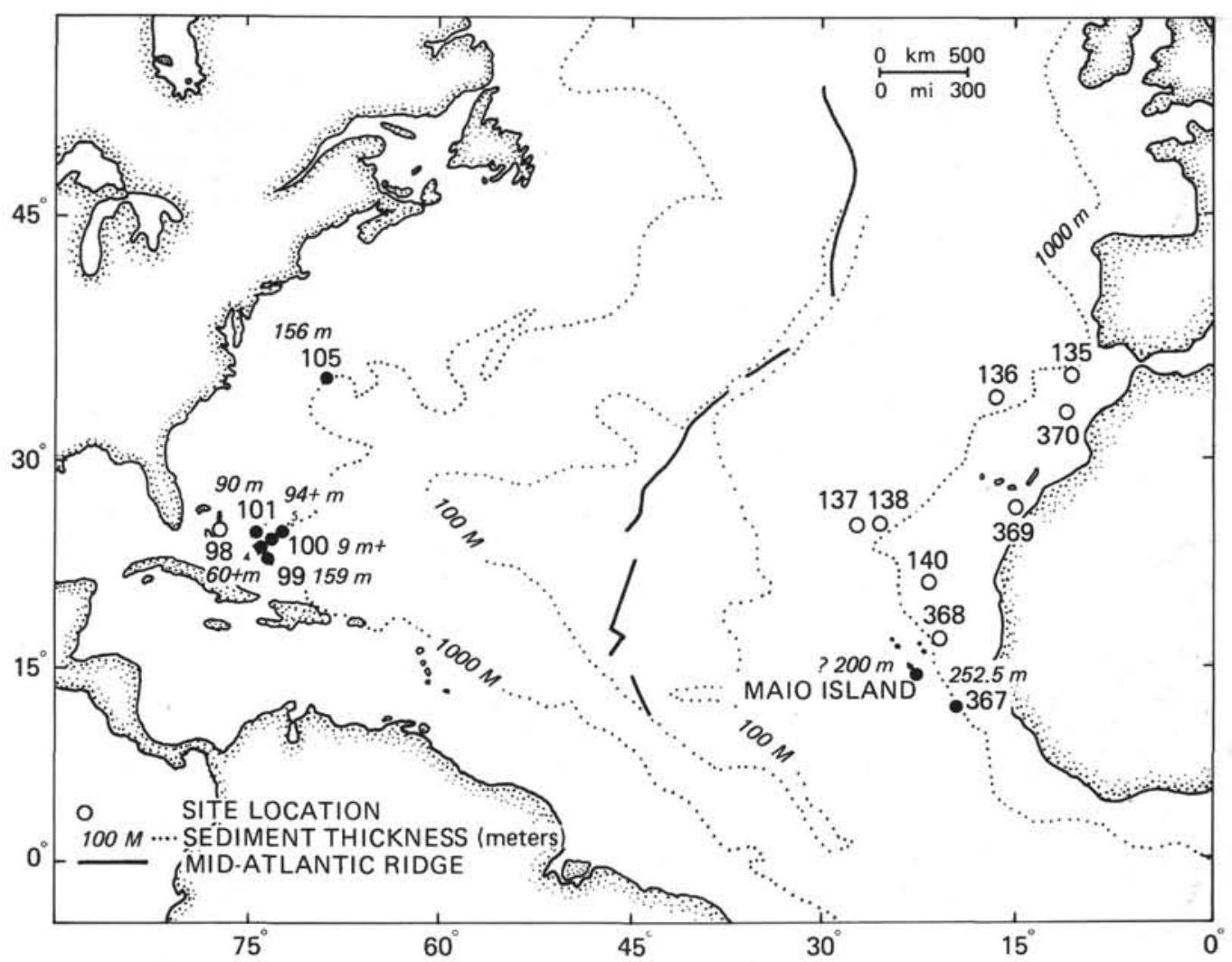

Figure 8. Occurrences and thickness of the Tithonian-Neocomian white chalky limestone unit in the central North Atlantic. Dark circle represents a site where this unit occurs.

TABLE 4

White Chalky Limestone Unit Occurrences in Central North Atlantic

\begin{tabular}{|c|c|c|c|c|}
\hline Region & $\begin{array}{l}\text { Locality } \\
\text { DSDP Site }\end{array}$ & Core & $\begin{array}{l}\text { Sub-sea Depth } \\
\text { (thickness) } \\
\text { (m) }\end{array}$ & Age \\
\hline Cape Verde Basin & 367 & 25-32, Section 5 & $-5649.5(252.5)$ & Barremian-Tithonian \\
\hline Cape Verde Archipelago & Maio Island & - & - & Hauterivian-Tithonian \\
\hline \multirow[t]{4}{*}{ Cat Gap } & 4 & $4-5$ & $-5509.5(60+)$ & Neocomian-Tithonian \\
\hline & 5 & $4 \mathrm{~A}-7 \mathrm{~A}$ & $-5539(94+)$ & Hauterivian-Tithonian \\
\hline & $99 \mathrm{~A}$ & $3-11$ & -4968 (159) & Neocomian-Tithonian \\
\hline & 100 & 1 & $-5538(9+)$ & Valangian-Tithonian \\
\hline Blake-Bahama Ridge & $101 \mathrm{~A}$ & $9-10$ & $-5477(90+)$ & Neocomian \\
\hline Hatteras Abyssal Plain & 105 & 18-33, Section 1 & $-5682(156)$ & Neocomian-Tithonian \\
\hline
\end{tabular}

and palygorskite were identified by Zemmels et al. (1972) at Sites 105, 101A, and 99A. Palygorskite dominates the clay mineral suite at Site 100. The other terrigenous components are minor silt-sized quartz, plagioclases, mica, finely disseminated pyrite, and traces of heavy minerals. Some of the albite crystals present in the limestones at Site 367 may be authigenic. Finely disseminated sapropel is common in the blackish colored marl interbeds (Plate 7, Figures 2,3) in which quartz silt occasionally occurs (Plate 7, Figure 3).

\section{Depositional Environment}

The white chalky limestone unit is a texturally homogeneous sedimentary unit with few depositional features except bioturbation and rare intraclasts near its lower boundary (Plate 6, Figure 6). With the exception of nannoplankton and radiolarians, fauna are scarce; this is probably indicative of pelagic deposition in a deep bathyal environment. Compared to the underlying unit, the white chalky limestones were deposited in a deeper environment, but still above carbonate compensation depth. The relative paucity of planktonic foraminifers indicates deposition below the lysocline for foraminifers, which corresponds to a water depth between 3000 and 4500 meters in recent oceans (Bosellini and Winterer, 1975). From these data an average water depth of 4000 meters is suggested for the deposition of the white chalky limestone unit. This interpretation is supported by Stahlecker's (1934) observation, that the macrofauna in a comparable limestone sequence at Maio Island is bathyal.

\section{Age}

The late Tithonian age of the lower boundary of the white chalky limestone has been established from the occurrence of calpionellids (Lehman, 1972 and this report) and foraminiferal fauna (Luterbacher, 1972; Ewing, Worzel, et al., 1969; see also Site Report 
Chapters, this volume). The age of the upper boundary varies due to the scarcity of the fauna and can be defined as Neocomian with the youngest beds dated Hauterivian at the Cat Gap area (Site 5; Ewing, Worzel, et al., 1969).

Using the Hauterivian and Tithonian as age limits of the unit and the absolute age table of van Hinte (Berggren et al., 1975), depositional rate of the white chalky limestones in the Cape Verde Basin was 14 $\mathrm{m} / \mathrm{m} . \mathrm{y}$., which is more than twice the depositional rate of the underlying reddish brown argillaceous limestone unit in the same region.

Sediments of the white chalky limestone unit are comparable to the Maiolica facies of the Alps (Garrison, 1967). Bernoulli (1972) suggests that they correspond to the Maiolica and Marne a Fucoidi. The Marne a Fucoidi, which consist of varicolored marls, are equivalent to the Scaglia Variegata of the southern Alps of Barremian-Aptian age (Luterbacher and Premoli-Silva, 1962), and is thus in part younger than the white chalky limestone unit. The contact with the overlying unit is transitional.

\section{Black Bituminous Shale Unit}

The unit is composed of black and dark gray bituminous shale and marl with relatively high interstitial methane content. Shales are widespread in the northern Atlantic (Figure 9, Table 5) (Ewing, Worzel, et al., 1969; Hollister, Ewing, et al., 1972; Hayes, Pimm, et al., 1972) and their occurrence extends southward into the southern Atlantic (Bolli, Ryan, et al., 1975), and probably as far as the Cuvier Abyssal Plain off western Australia (Veevers, Heirtzler, et al., 1974). The composition of the sediments varies and two facies and one subfacies were recognized: a variegated claystone subfacies, a black shale facies, and a dark gray marl facies.

The variegated claystone subfacies is present in the Cape Verde Basin (Site 367, Core 24). This unit is composed of variegated shales and marls, which overlie limestones of the white chalky limestone. The claystone is dark reddish brown, dark greenish gray and dark gray, bioturbated and composed of clay minerals with rare quartz silt, zeolites, and organic matter (Plate 7, Figure 4). Clay is stained red by hematite. Rare radiolarian casts are filled by chalcedony and/or by the clay. Well-preserved planktonic foraminifers and various agglutinated foraminifers are occasionally common.

Where the variegated subfacies is not developed, the light gray limestones grade upward into the black shale (Plate 9, Figure 1). The black shale is highly carbonaceous and alternates with thin laminae of greenish gray bituminous clay and with thin laminae of light gray marl (Plate 9, Figure 2) near to the base and the top of the sequence. Zeolites, clay minerals, amorphous organic matter, subordinate quartz silt-size grains, pyrite, siderite, and mica are the shale constituents (Plate 7, Figure 5). In the silty laminae, quartz silt is dominant, and heavy minerals common. The organic matter in the shale occurs as very fine, siltsized, amorphous light brown spherules probably derived from noncalcareous colonial algae and rare pollen and wood fragments. The $\mathrm{C}_{\text {org }}$ in the shales varies from $3 \%$ to $28 \%$. Fossils in shales are rare, but include nannoplankton, planktonic and benthic foraminifers, pyritized Radiolaria casts, and fish debris. Foraminifers (Plate 8, Figure 2) and nannoplankton (Plate 8, Figure 3) are commonly concentrated in lighter silty laminae (Plate 7, Figure 6) and were probably deposited by turbidity currents.

The second, less sampled, lithofacies consists of olive-black silty nannofossil marl alternating with dark greenish-gray marl, which was penetrated in the Canary Basin at Site 137 and on the Sahara continental slope at Site 369 . The silty marls represent transitional facies between the black shales and the light calcareous sediments deposited at shallower depth on continental shelves and slopes (Plate 9, Figure 2). The marls are a mixture of nannoplankton and clay minerals, with minor quartz silt, feldspars, and heavy minerals. Sapropel is very common. Planktonic foraminifers are common and benthic foraminifers are rare. Belemnite fragments occasionally occur. The presence of nannoplankton and well-preserved planktonic foraminifers indicate deposition above the carbonate dissolution level.

North of the Spanish Sahara in the Moroccan Basin the deposition of black bituminous shales was masked by an extensive influx of terrigenous turbidites, which diluted the overall content of organic matter in the sediments. In the Moroccan Basin the time-equivalent deposits to the upper part of the white chalky limestone unit and the black bituminous shale unit are hemipelagic, dark gray to dark greenish gray, and oliveblack calcareous silty claystones, interbedded with siltstones and fine-grained sandstone laminae and thin beds. These deposits are defined as a separate unit (Table 1). Nannoplankton and planktonic foraminifers in the latter unit are rare and suggest depositional conditions similar to the Cape Verde Basin, but somewhat modified by turbidite deposition.

The black shale facies extends into the southern Atlantic, where similar sediments were identified in the Angola Basin (Sites 365, 364), at the crest of the Walvis Ridge (Site 363), and in the Cape Basin (Site 361) by Bolli, Ryan, et al. (1975).

\section{Depositional Environment}

At Site 367 the relative paucity of carbonates in the variegated subfacies of the black shale unit, with foraminifers occurring in foraminifer-enriched laminae, may indicate that the foraminifers were displaced from a shallower environment, and redeposited below the CCD level by turbidity currents. The coloration of the marls might have resulted from temporary increase of oxygen in the bottom waters or diminished input of organic matter (Dean et al., this volume).

Sediments of the variegated subfacies were dated at Site 367 as Aptian by palynology (Williams, this volume) and by nannoplankton as Barremian-early Aptian (see Site Report Chapters, this volume). The variegated subfacies can be compared with the Scaglia Formation developed in the central and southern Alps which is early Aptian-Cenomanian in age (Grunau, 1965), although the planktonic foraminifers in marls of the Scaglia Variegata suggest it was deposited above the carbonate lyslocline for foraminifers. 


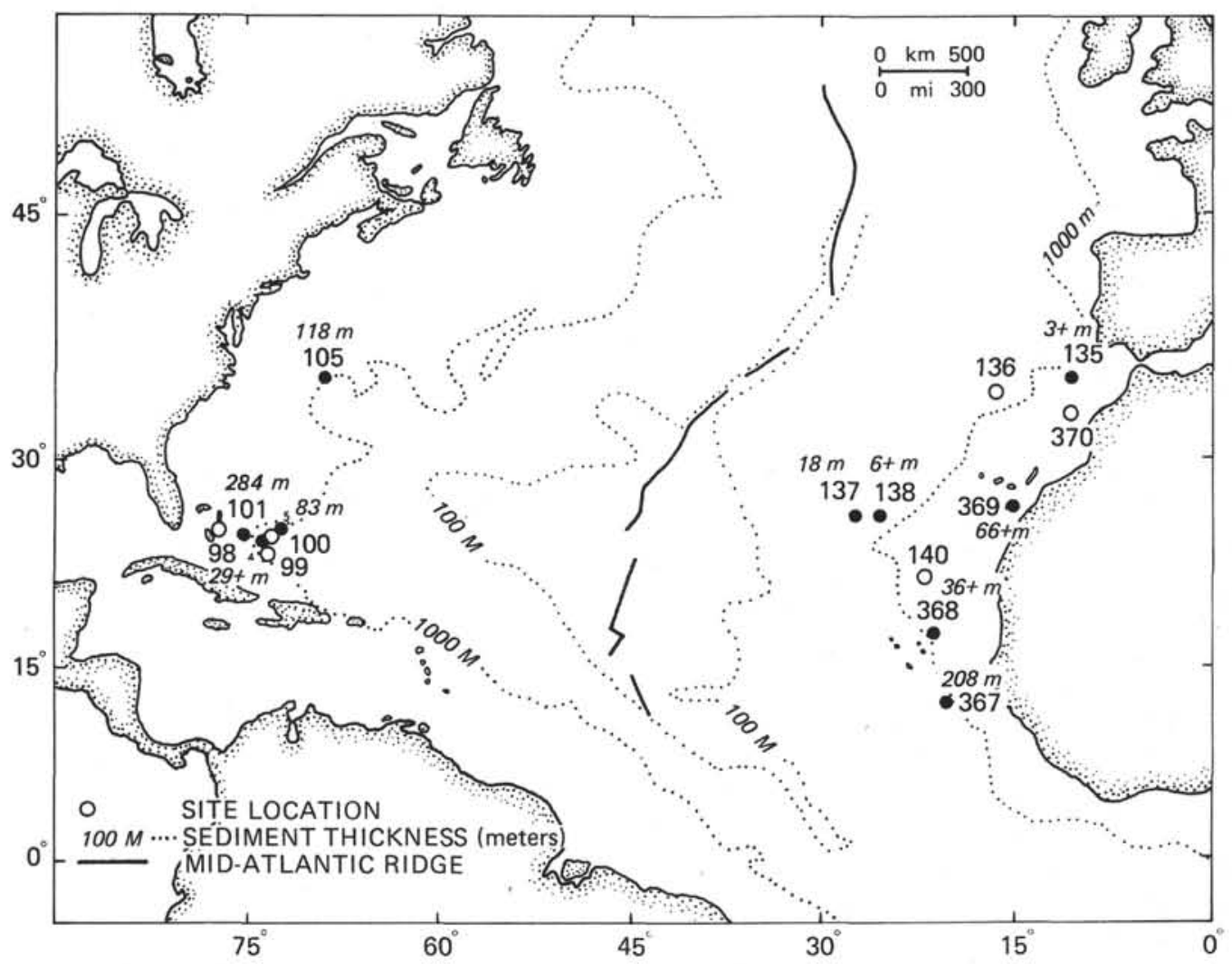

Figure 9. Occurrences and thickness of the Cretaceous black bituminous shale unit in the central North Atlantic. Dark circle represents a site where this unit occurs.

TABLE 5

Black Bituminous Shale Unit Occurrences in Central North Atlantic

\begin{tabular}{|c|c|c|c|c|}
\hline Region & $\begin{array}{l}\text { Locality } \\
\text { DSDP Site }\end{array}$ & Core & $\begin{array}{l}\text { Sub-sea Depth } \\
\text { (thickness) } \\
\text { (m) }\end{array}$ & Age \\
\hline Cat Gap & $4 / 4 \mathrm{~A}$ & $2 \mathrm{~A}-3$ & $-5464(29+)$ & Early Cenomanian-late Albian \\
\hline Blake Bahama Ridge & $5 / 5 \mathrm{~A}$ & $3-3 A$ & $-5425(83)$ & ? - early Albian \\
\hline Blake Bahama Ridge & $101 \mathrm{~A}$ & $4 A-8 A$ & $-5128(284)$ & Albian-Barremian \\
\hline Hatteras Abyssal Plain & 105 & $9-17$ & $-5547(118)$ & Cenomanian-Neocomian \\
\hline Cape Verde Basin & 367 & $18-24$ & $-5384(208)$ & Cenomanian-?Barremian \\
\hline Cape Verde Rise & 368 & $60-63$ & $-4326(36+)$ & Upper Cretaceous \\
\hline $\begin{array}{l}\text { Canary Basin and } \\
\text { continental slope } \\
\text { off Spanish Sahara }\end{array}$ & $369 \mathrm{~A}$ & $41 \mathrm{~A}-47 \mathrm{~A}$ & $-2192(66+)$ & Albian-upper Aptian \\
\hline $\begin{array}{l}\text { Canary Basin and } \\
\text { continental slope } \\
\text { off Spanish Sahara }\end{array}$ & 138 & 6 & $-5713(6+)$ & Cenomanian \\
\hline Canary Basin and & 137 & $7-16$ & $-5617(18)$ & Early Turonian-late Albian \\
\hline $\begin{array}{l}\text { Horseshoe Abyssal } \\
\text { Plain }\end{array}$ & 135 & 9 & $-4837(3+)$ & Early Aptian \\
\hline
\end{tabular}

The depositional conditions of the black shale unit were similar over the whole southern North Atlantic and South Atlantic, and may extend to Site 263 off western Australia (Veevers et al., 1972). If we accept Hurley's (1968) reconstruction of Mid-Cretaceous Gondwanaland, then it is possible that the very specific depositional conditions of the Cape Basin extended up to Site 263 which at that time would be situated just north of Madagascar. However, the euxinic basin of western Australia could have developed independently of the Atlantic basin (Veevers and Heitzler, 1974) and in that case the similarity would be only coincidental.

Mineralogical composition and fossils indicate mainly pelagic deposition in a bathyal environment, near or below the carbonate compensation depth, for the black shale facies, and deposition above the carbonate lysocline for the olive-black marls. The black shales are not strictly depth-dependent as can be seen from the transition to a shallower, bituminous marl lithofacies off the Spanish Sahara at Site 369 (see site description).

The Lower Cretaceous black shale facies are usually interpreted as representing bottom water stagnation (euxinic conditions) in a restricted early-Atlantic Ocean (Lancelot et al., 1972; Bolli, Ryan, et al., 1975). An alternative hypothesis is presented by Dean et al. (this volume) who suggest that the black clays are a result of variations in the rate of supply or organic matter, which 
influenced the redox conditions in the sediment. Reduced bottom water circulation would help to maintain reduced conditions above sediment-water interface.

A completely different and less probable solution to the origin of the bituminous shales is suggested by Jordan (1974), who explains the occurrence of bituminous shales in the Jurassic and Cretaceous by special conditions introduced by halokineses, with intense release of salt and the development of salt brines. The effect of the resulting rich salt supply should, according to Jordan, appear in a development of "special facies"-bituminous shales.

\begin{abstract}
Age
The time boundaries established for the black bituminous shale unit in the central North Atlantic vary slightly as a result of discontinuous coring and impoverished microfauna. The biostratigraphic studies published in the DSDP Initial Reports indicate that the lower boundary of the sequence can be established as Barremian-Aptian, with an early Aptian age being most common. The age of the upper boundary ranges from Cenomanian (Site 105, where the black shale is abruptly terminated by a probable hiatus) to Campanian (Site 138), with the most frequent age being Turonian.
\end{abstract}

\section{Grayish-green Claystone-Intraclast Sandstone Unit}

This unit is a hemipelagic sequence composed of various shades of olive-black and greenish-colored claystone, nannofossil claystone, and silty clay interbedded with thin beds of siltstone, sandstone, and conglomerate (Plate 9, Figure 3). This sequence was penetrated in the Moroccan Basin at Site 370 (Cores 2751) (Figure 10; Table 6; see also Site Chapter 370).

The upper boundary of the unit is transitional and occurs in the zones spanned by Cores 31 to 27 .

Sediments in this unit are olive-black, grayish-green, pale green to bluish green, calcareous silty claystone and less common nannofossil-bearing claystone, interbedded with argillaceous siltstone, sandstone, rare gravelly claystone, and conglomerates.

The claystone which dominates the sequence is composed of illite, kaolinite, mixed-layered illitemontmorillonite, and rare chlorite. Quartz silt is rare to abundant, and feldspars, heavy minerals, glauconite, dolomite rhombs, and pyrite are rare. Nannoplankton and planktonic foraminifers occur occasionally, but the more common microfossils are calcisphaerulids and benthic foraminifers. Amorphous sapropel is concentrated in some of the claystones. In siltstones and sandstones the coarse fraction is composed of a variety of intraclasts, quartz grains, feldspars, glauconite, heavy minerals, and bioclasts. The intraclasts are reddish, brownish, and greenish argillaceous siltstone, mudstone, calcareous siltstone, and limestones (Plate 10, Figure 3). The most common limestone intraclasts are micrite and biomicrite with foraminifers, ostracodes, and occasionally calpionellids. Less frequent are peloid and skeletal grainstones, wackestones, dolomicrites, peldomicrites, oödolomicrites, and microdolosparites (Plate 10, Figure 2).
The maximum size of intraclasts in thin sections averages between 1 and $2 \mathrm{~mm}$ but reach $4 \mathrm{~cm}$ in the core. Moderately well rounded and moderately sorted quartz grains, some of them coated by iron oxide are also found in the sandstone. Minor constituents are feldspars, glauconite, heavy minerals (leucoxene, rutile, tourmaline, and zircon), and rare basalt fragments. Heavy minerals are frequently concentrated into fine laminae (Plate 10, Figure 4), which indicates reworking of deposited sediments. Sapropel is relatively common and fine debris of coalified wood is occasionally present. Phosphatic grains occur in some of the beds. Fish debris, otholites, foraminifers, mollusk fragments and rare echinoderm spines, belemnite fragments, and calpionellids are associated with the intraclasts. This association of intraclasts and micro- and macro-fossils suggests that the fossils are mainly reworked from the shelf and slope areas.

Detrital grains in siltstones, sandstones, and conglomerates are cemented mainly by ferroan calcite, and less often by low-iron sparry calcite. The cement has poikilotopic texture; syntaxial overgrowth and sparry mozaic fabric are also common. Dominance of the iron-rich sparry calcite is surprising and demonstrates that ferrous iron-rich calcite can form as a deepwater submarine cement and is not necessarily related to precipitation in the phraetic zone as suggested by Bathurst (1971). The coarse-grained beds are tightly cemented, with no porosity remaining. Strong submarine cementation of coarse clastic beds introduces a negative factor for hydrocarbon reservoir development in the Atlantic Ocean rise areas.

\section{Depositional Environment}

The sparse occurrence of microfossils in the grayish green claystone-intraclast sandstone unit and the common presence of sapropel suggest deposition in an occasionally euxinic environment similar to the black bituminous shale unit. Deposition occurred at a depth near the calcite compensation level. The pelagic deposition was modified by a strong influx of distal turbidites interpreted to represent a deep-sea outer fan, and by local reworking by contour currents. The common occurrence of upper sharp boundaries to the coarser clastic beds may relate to overbank deposition along poorly defined channels (Walker and Mutti, 1973). Frequently occurring contorted and slump structures indicate location of the site on the paleoslope.

The dominance of carbonate intraclasts in turbidite deposits demonstrates that low to moderate energy carbonates were deposited on the outer shelf area off Morocco. The occurrence of dolomite clasts in some of the turbidite beds suggests erosion of older, probably Lower Jurassic rocks, which in the Essaouira basin are underlain by Triassic red beds. The iron oxide-stained quartz grains are either derived from erosion of these Triassic deposits, or these grains represent wind borne quartz grains from a desert area.

\section{Age}

The age of the grayish green claystone-intraclast sandstone unit was interpreted from nannoplankton, 


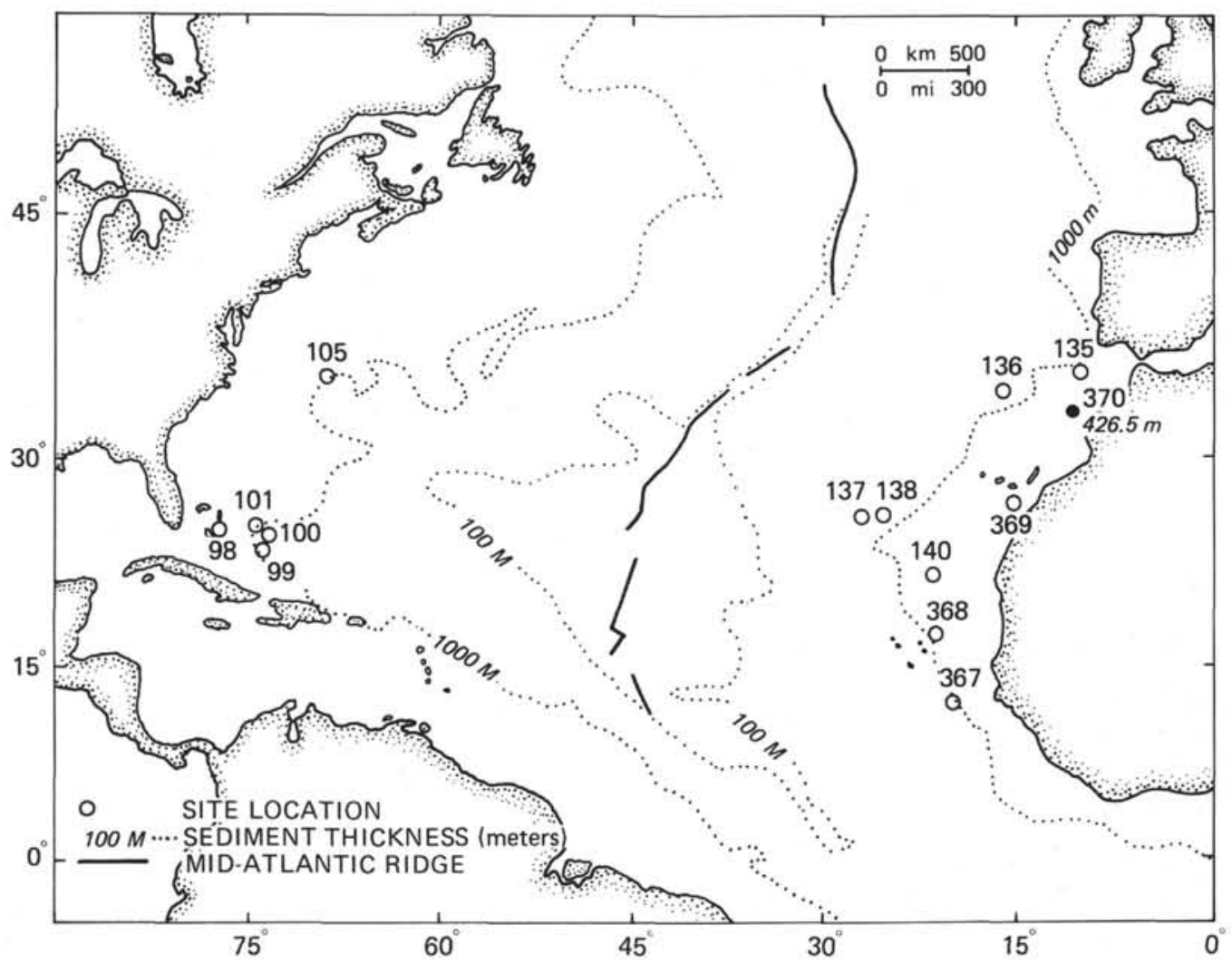

Figure 10. Occurrences and thickness of the Lower Cretaceous grayish green claystone intraclast sandstone unit in the central North Atlantic. Dark circle represents a site where this unit occurs.

TABLE 6

Grayish-green Claystone-Intraclast Sandstone Unit Occurrence in Central North Atlantic

\begin{tabular}{|c|c|c|c|c|}
\hline Region & $\begin{array}{l}\text { Locality } \\
\text { DSDP } \\
\text { Site }\end{array}$ & Core & $\begin{array}{l}\text { Sub-sea Depth } \\
\text { (thickness) } \\
(\mathrm{m})\end{array}$ & Age \\
\hline Moroccan Basin & 370 & $27-51$ & $-4975(426.5+)$ & $\begin{array}{c}\text { Albian- } \\
\text { Valanginian }\end{array}$ \\
\hline
\end{tabular}

foraminifers, and palynomorphs studies as Valanginian to Albian (see Site Report Chapters, this volume; Williams, this volume). The sequence has a transitional contact with the overlying unit.

\section{Greenish Claystone Unit}

The greenish claystones, shales and marls, which overlie the black bituminous shale unit were penetrated by four holes (Table 7) along the northwestern African continental margin (Figure 11).

The unit is composed ot hemipelagic and pelagic sediments of a variable lithology depending on the position of the depositional site relative to the carbonate dissolution level. At Site 368 the olive-gray and dark greenish gray silty and sandy claystones and shales are cyclically interbedded (Plate 9, Figure 5). Silt and sand laminae and thin beds occur occasionally and porcellanite, chert nodules are rare. The argillaceous deposits are bioturbated (Plate 9, Figures $4,5)$. The microfossils in the shales are represented by a diverse assemblage of agglutinated foraminifers, but other calcareous microfossils are lacking. The lack of calcareous fossils at this site suggests deposition below carbonate dissolution level. Site 368 represents the deepest facies of the greenish claystone unit.

At Site 370 the sedimentary sequence is composed of nannofossil-bearing, homogeneous, dark greenish gray, rarely bioturbated claystones (Plate 8 , Figure 4), which in the lower part of the sequence are interbedded with thin silt and sandy laminae. The planktonic foraminiferal assemblage is rich, and foraminifers are well preserved, but benthics are rare. Nannoplankton become more frequent toward the top of the sequence and calcisphaerulids are present through the sequence.

The third facies variation was encountered at the upper continental slope off Spanish Sahara, at Site 369, where the sequence is composed of greenish gray highly bioturbated, argillaceous marls and chalks, with chert

TABLE 7

Greenish Claystone Unit Occurrences in the Central North Atlantic

\begin{tabular}{|c|c|c|c|c|}
\hline Region & $\begin{array}{l}\text { Locality } \\
\text { DSDP Site }\end{array}$ & Core & $\begin{array}{l}\text { Sub-sea Depth } \\
\text { (thickness) } \\
(\mathrm{m})\end{array}$ & Age \\
\hline Cape Verde Basin & 368 & $53-59$ & $\begin{array}{l}-4127 \\
(200\end{array}$ & Late Cretaceous \\
\hline $\begin{array}{l}\text { Spanish Sahara } \\
\text { Slope }\end{array}$ & 369 & $38-40$ & $\begin{array}{l}-2163.5 \\
(28.5)\end{array}$ & $\begin{array}{l}\text { Early Maestrichtian- } \\
\text { Coniacian-Santonian }\end{array}$ \\
\hline $\begin{array}{l}\text { Spanish Sahara } \\
\text { Lower Rise }\end{array}$ & 140 & $? 7-8$ & $\begin{array}{l}-5068 \\
(86+)\end{array}$ & $\begin{array}{l}\text { ?Paleocene- } \\
\text { Maestrichtian }\end{array}$ \\
\hline Moroccan Basin & 370 & $20-26$ & $\begin{array}{l}-4899 \\
(126.5)\end{array}$ & $\begin{array}{l}\text { Late-early } \\
\text { Cenomanian }\end{array}$ \\
\hline
\end{tabular}




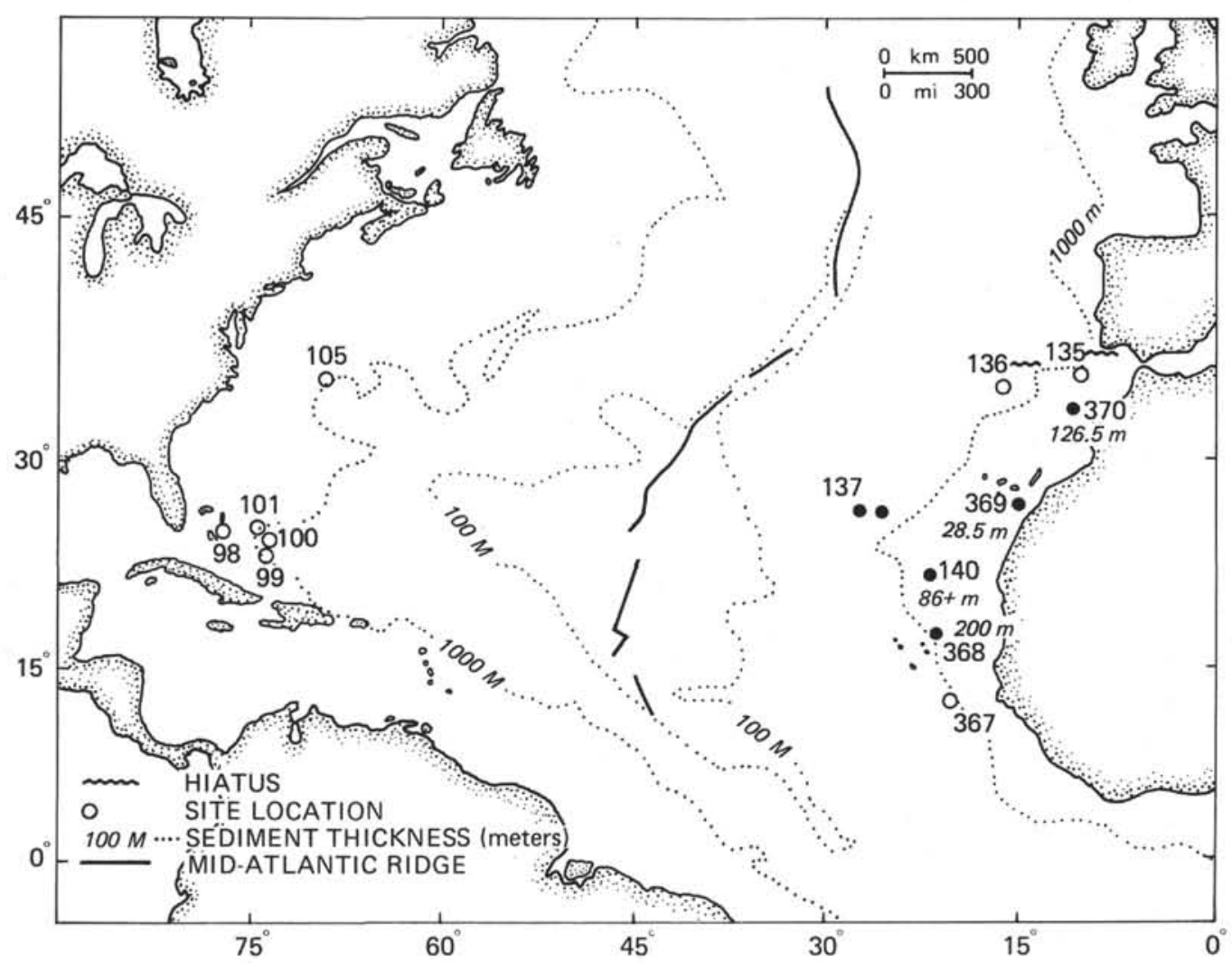

Figure 11. Occurrences and thickness of the Late Cretaceous greenish claystone unit in the central North Atlantic. Dark circle represents a site where this unit occurs.

and porcellanite. This facies appears to be a transitional unit between deep water pelagic and hemipelagic clays and limestone-shale sequences outcropping on the Morocco and Spanish Sahara coast. Due to lack of detailed lithological data from the Spanish Sahara Shelf and the transitional character of the unit in Site 369, the argillaceous marls and chalks are provisionally included in the greenish claystone unit.

As a result of deposition on the continental slope, slumps frequently occur in the sequence at Site 369 . The nannoplankton and pelagic foraminifers are abundant in chalks and radiolarians are rare to common. At this site sediments were deposited well above the carbonate dissolution level.

The clay minerals of the unit are dominated by montmorillonite and palygorskite with minor illite, kaolinite, and chlorite. Zeolites, quartz silt grains, and traces of feldspars, mica, dolomite rhombs, fish debris, sapropel, and heavy minerals occur as minor constituents. At Site 140 hornblende, zircon, rutile, apatite, tourmaline, and topaz were identified (Hayes and Pimm, 1972). The mineralogy of both silt and sand laminae is similar, consisting of angular to subrounded, well-sorted quartz, with minor feldspars and rare mica and heavy minerals. Fish debris and sapropel are also occasionally present. At Site 140 feldspars increased up to $10 \%-20 \%$, with microcline more abundant than sodic plagioclase and sanidine, which suggests derivation of the sandstone from a granite source, possibly the Requibate Massif (Hayes and Pimm, 1972).
In summary, the deposition of the greenish claystone unit varies from deep marine abyssal to an upper continental slope-epibathyal environment.

\section{Age}

The stratigraphic span of the sequence is not well established and it is interpreted as Late Cretaceous (see site chapters, this volume). It overlies the black bituminous shale and/or the grayish green claystoneintraclast sandstone unit with a transitional contact. It is separated from the overlying Tertiary sequences by an unconformity at Site 370 , by a thin varicolored shale unit at Site 368, and is gradational into Tertiary at Site 369. At the latter site the Tertiary sequence differs from the greenish claystone unit by a higher degree of lithification. The overlying Tertiary sediments are argillaceous chalks and limestones, with common porcellanite and chert nodules.

The greenish claystone unit is time synchronous with the varicolored zeolitic clays unit deposited in the North American and Cape Verde basins. Sites 137 and 138 , located in the western part of the Canary Basin, are somewhat transitional in character between the greenish claystone unit and the varicolored zeolitic clay unit, but because of the presence of multicolored layers at these two sites, they are grouped with the latter.

\section{Varicolored Zeolitic Clay Unit}

Varicolored zeolitic silty clay of early Tertiary-Late Cretaceous age overlie black bituminous shale unit in 
the Cape Verde Basin (Site 367, this volume), on the western side of the Canary Basin (Sites 137 and 138; Hayes, Pimm, et al., 1972), in the Hatteras Abyssal Plain (Site 105; Hollistery, Ewing, et al., 1972), on the flanks of the Bermuda Rise (?Site 7; Ewing, Worzel, et al., 1969). The regional extent of the sequence appears to be limited to the western North Atlantic, with the northern boundary in the vicinity of the New England Seamount chain (Table 8, Figure 12).

The multicolored clays of Sites 105 and 367, according to Lancelot (personal communication), may not be correlative because the clays at Site 105 were interpreted as volcanic (Lancelot et al., 1972) and the clays at Site 367 appear to be normal deep-sea clays.

The lithologic character, color, and age of the variegated sequence in both North American and Cape Verde basins are very similar; this, with the dominant pelagic nature of the deposits, suggests that the sequences are part of the same lithostratigraphic unit. However, this correlation will remain tentative unless several more wells are drilled off northwestern Africa.

Sediments of this varicolored unit are zeolitic silty clay with rare chert or porcellanite. The clays are only occasionally mottled and faintly laminated, and very rarely bioturbated. Most of the sedimentary sequence is homogeneous and the only visible difference is color banding. The color bands range through various shades of reddish brown, yellow, orange, blue-green, greenish gray, and white. The color bands seem always to be separated by sharp boundaries. Calcium carbonate is absent, but may occur in the transitional zones near the unit boundaries where the content of nannoplankton and foraminifers increases. The dominant components of the clay are montmorillonite and less palygorskite, illite, and rare kaolinite. Zeolites, principally clinoptilote and heulandite, and minor philipsite, are common at Site 105 (Hollister, Ewing, et al., 1972). The additional minor claystone components are quartz silt, feldspars, mica, heavy minerals, and pyrite. The abundant iron and manganese oxide minerals are largely responsible for the sediment color. The sedimentary sequence is almost completely devoid of micro- and macrofossils, with only occasional traces of primitive agglutinated foraminifers, Radiolaria, and fragments of fish bones. Nannoplankton may be present near the unit boundaries, as at Site 137, Core 2 (Hayes, Pimm, et al., 1972).

TABLE 8

Varicolored Zeolitic Clay Unit Occurrences in the Central North Atlantic

\begin{tabular}{lcccl}
\hline \multicolumn{1}{c}{ Region } & $\begin{array}{c}\text { Locality } \\
\text { DSDP Site }\end{array}$ & Core & $\begin{array}{c}\text { Sub-sea Depth } \\
(\text { thickness) } \\
(\mathrm{m})\end{array}$ & \multicolumn{1}{c}{ Age } \\
\hline $\begin{array}{l}\text { Cape Verde } \\
\text { Basin } \\
\text { Canary Basin }\end{array}$ & 367 & $14, \mathrm{CC}-17$ & $\begin{array}{l}-5146 \\
(236.5)\end{array}$ & Upper Cretaceous \\
$\begin{array}{l}\text { Canary Basin } \\
\text { Hatteras Abyssal }\end{array}$ & 138 & $3-5$ & $\begin{array}{l}-5471 \\
(158)\end{array}$ & $\begin{array}{l}\text { ? Early Tertiary- } \\
\text { Campanian }\end{array}$ \\
$\begin{array}{l}\text { Plain } \\
\text { Bermuda Rise }\end{array}$ & 137 & $2-6$ & $\begin{array}{l}-5460 \\
(126)\end{array}$ & $\begin{array}{l}\text { ? Early Tertiary- } \\
\text { Early Campanian } \\
\text { Early Tertiary- } \\
\text { (undated) over- } \\
\text { lying Cenomanian }\end{array}$ \\
& 27 & $5-9$ & $\begin{array}{l}-5502 \\
\text { Undated, under- } \\
\text { lies Eocene }\end{array}$ \\
\hline
\end{tabular}

\section{Depositional Environment}

The lack of calcareous micro- and macrofossils in the varicolored zeolitic clays indicate that the sequence was deposited below carbonate compensation depth. The abundance of oxides suggest that the depositional environment was well oxygenated. The sediment composition is dominated by palygorskite and zeolites. The mineralogical assemblages of the sequence is interpreted to represent dominantly pelagic deposits with abundant authigenic minerals.

\section{Age}

The age of the sequence is not well defined because of lack of calcareous micro- and macrofossils and also lack of siliceous microfossils. The age can be derived only from the strata superposition. The age of the base of the unit varies from upper Cenomanian to Campanian and of the upper boundary from Maestrichtian to Paleocene with the latter at Site 105 being as young as Miocene. The varicolored zeolitic clay unit in the central North Atlantic is overlain by Tertiary zeolitic clays with cherts and porcellanite, and/or by greenish gray hemipelagic muds.

\section{SUMMARY}

Based on an excellent section at Site 367, a reasonably precise time-stratigraphic and lithostratigraphic correlation is now possible between western and eastern North Atlantic DSDP holes which have penetrated into the Mesozoic sequences. The wide lateral distribution, lithological similarity, and reasonable time synchronism of the Mesozoic sedimentary sequences in the central North Atlantic (Figures 3, 4, 5) permits recognition of a succession of seven lithostratigraphic units (Table 1) represented in ascending order by Oxfordian greenish gray limestone, Oxfordian-Kimmeridgian reddish brown argillaceous limestone, Tithonian-Hauterivian white chalk, AptianCenomanian black bituminous shale, ValanginianAlbian greenish gray claystone with turbidites, Late Cretaceous greenish colored claystone, late Cenomanian-Maestrichtian to Paleocene varicolored zeolitic clay.

Study of the microfacies of the Jurassic sedimentary sequences narrows the span of lithostratigraphic and biostratigraphic units previously very broadly identified. The fossil assemblages (protoglobigerinids, Globochaete, Saccocoma, filaments, radiolarians, and aptychi) in the limestone overlying basalt, and the results obtained from calculations of depositional rates for the Jurassic indicate that the oldest sediments in the central North Atlantic are not older than lower upper Oxfordian, which confirms the 145 m.y. age of the Keathley anomaly M-25 (Larson and Hilde, 1975). These limestones were deposited in a pelagic realm and a bathyal environment. The greenish gray argillaceous limestone and marl in the Cat Gap area are the oldest sediments penetrated in the southern North Atlantic, but might, at least in part, be time synchronous with the reddish brown limestone and chalk penetrated in the Cape Verde Basin and the North American Basin. 


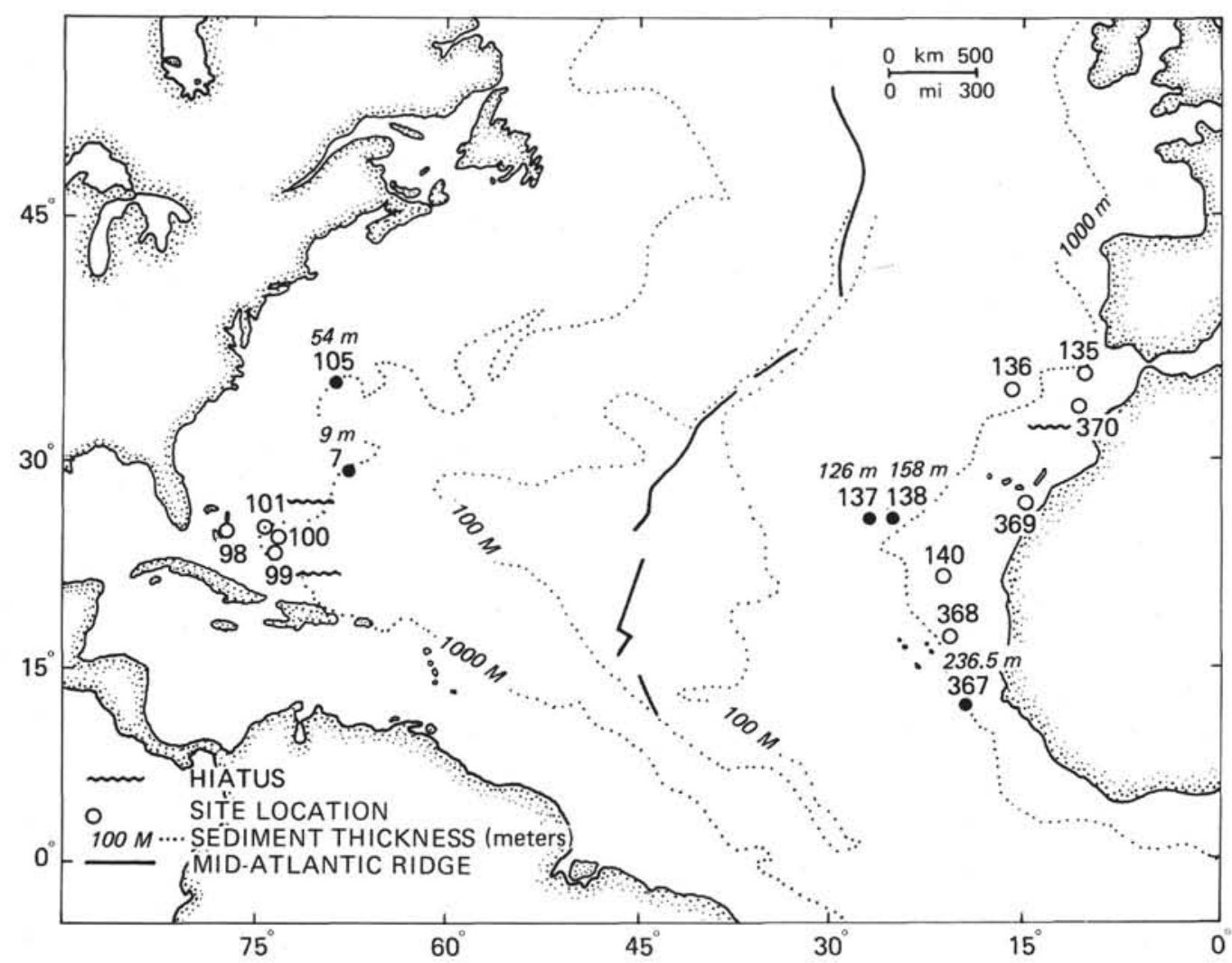

Figure 12. Occurrences and thickness of the Late Cretaceous-early Tertiary varicolored zeolitic clay unit in the central North Atlantic. Dark circle represents a site where this unit occurs.

The reddish coloration of the limestone is related to hematite staining of the clay minerals. It was probably acquired during early diagenesis as a result of a proximity to volcanic rocks, intrastratal alteration of iron-bearing minerals by migrating ground water, and the presence of interstitial chemical conditions favoring the formation and preservation of iron oxides, a process similar to that proposed by Walker (1974). The reddish brown limestones are subdivided into the radiolarian and filament microfacies which are Oxfordian in age and the Saccocoma microfacies which is considered to represent the Kimmeridgian. The approximate Kimmeridgian-Tithonian boundary is marked by a relatively sharp color change accompanied by a strong change of the macrofossil assemblage. The pelagic-carbonate deposition continued into Barremian-Hauterivian, when the sea bottom subsided below the carbonate dissolution level. At this time carbonate deposition ceased and black bituminous shales were deposited in an euxinic depositional environment.

The extensive development of euxinic conditions is thought to be related to the increased supply of organic matter and sluggish deep-water circulation. The reducing conditions at the sea bottom extended into Late Cretaceous in the Moroccan and Canary basins, where dark green clays, marls, and chalks were deposited. The synchronous deposits to the greenish claystones unit in the Cape Verde and North American basins are pelagic varicolored zeolitic clays, which indicate the re-establishment of deep-water circulation and oxygenated bottom waters during Late Cenomanian in the western North Atlantic. The presence of oxygenated bottom waters in the western North Atlantic further indicates that the deep-water circulation was more intensive in the North American and Cape Verde basins than along the northwestern African margin.

A hiatus separates Late Cretaceous sequences from Cenozoic in the Moroccan Basin and North American Basin, but in other areas deposition continued without interruption into the Cenozoic. The hiatuses are most probably related to periods of nondeposition and bottom current activity.

The Mesozoic, particularly the Late Jurassic sequences in the southern North Atlantic, are comparable to coeval circum-Mediterranean lithofacies (Bernoulli, 1972); the reddish-brown argillaceous limestone unit with the Rosso ad Aptici, the white chalky limestone unit with Maiolica, and the variegated subfacies of the black bituminous shale unit with the Scaglia Variegata Formation.

The presence of pelagic Tethyan facies in the central North Atlantic indicates an open marine connection between the Tethys and this ocean, at least since early Oxfordian. The oldest sediments yet penetrated in the central North Atlantic were deposited on oceanic crust in a bathyal environment. 


\section{REFERENCES}

Assereto, R., Clari, P.A., Gaetani, M., Massari, F., Sorbini, L., and Sturani, C., 1975. Excursion N. A-14 Field Guide: Ninth Intern. Congr. Sedimentology, Nice, 1975.

Aubouin, J., 1964. Réflexions sur le faciés "ammonitico rosso": Bull. Soc. Geol. France, v. 7, p. 475-501.

Aumento, F., Melson, W.G., et al., 1974. Leg 37-the volcanic layer: Geotimes, p. 16-18.

Azéma, J., Bourrouilh, R., Champetier, Y., Fourcade, E., and Rangheard, Y., 1974. Rapports stratigraphiques, paléogéographiques et structuraux entre la chaine Ibérique, les Cordillères Bétiques et les Baléares: Bull. Soc. Géol. France, v. XVI, p. 101-237.

Baas Becking, L.G.M., Kaplan, I.R., and Moore, D., 1960. Limits of the natural environment in terms of $\mathrm{pH}$ and oxydation-reduction potentials: J. Geol., v. 68 , p. $243-$ 284.

Bathurst, R.G.C., 1971. Carbonate sediments and their diagenesis: Developments in sedimentology 12: New York (Elsevier).

Benson, W.E., Sheridan, R.E., et al., 1976. Deep Sea Drilling in the North Atlantic: Geotimes, p. 23-26.

Berggren, W.A., McKenzie, D.P., Sclater, J.G., and van Hinte, J.E., 1975. World-wide correlation of Mesozoic magnetic anomalies and its implications: discussion and reply: Geol. Soc. Am. Bull., v. 86, p. 267-272.

Berner, R.A., 1969. Migration of iron and sulfur within anaerobic sediments during early diagenesis: Am. J. Sci., v. 267 , p. $19-42$.

Bernoulli, D., 1972. North Atlantic and Mediterranean Mesozoic facies: A comparison. In Hollister, C. D., Ewing, J.I., et al., Initial Reports of the Deep Sea Drilling Project, Volume 11: Washington (U.S. Government Printing Office), p. 801-871.

Bernouilli, D., and Jenkyns, H.C., 1974. Alpine, Mediterranean, and Central Atlantic Mesozoic facies in relation to the early evolution of the Tethys. In Dott, R.H., Jr., and Sharer, R.H. (Eds.), Modern and ancient geosynclinal sedimentation: Soc. Econ. Paleontol. Mineral. Spec. Publ. 19 , p. $129-160$.

Bryan, W.B., 1972. Textural and mineralogical relations of basalts from Sites 100 and 105. In Hollister, C.D., Ewing, J.I., et al., Initial Reports of the Deep Sea Drilling Project, Volume 11: Washington (U.S. Government Printing Office), p. 873-876.

Dabrio, C.J., Gonzales-Donoso, J.M., Rivas, P., and Vera, J.A., 1971. Geology of the sub-betic zone. American Geological Institute-Guidebook-Tenth International field institute 1971, p. 171-196.

Didon, J., Durand-Delga, M., and Kornprobst, J., 1973. Homologies géologiques entre les deux rives du détroit de Gibraltar, B.S.G.F., v. 7, p. 77-105.

Duff, K.L., 1975. Paleoecology of a Bituminous shale-the Lower Oxfordian Clay of Central England: Paleontology, v. 18, p. $443-482$.

Ewing, M., Worzel, L.J., et al., 1969. Initial Reports of the Deep Sea Drilling Project, Volume 1, Washington (U.S. Government Printing Office).

Garrison, R.E., 1967. Pelagic limestones of the Oberalm Beds (Upper Jurassic-Lower Cretaceous), Austrian Alps: Canadian Petrol. Geol. Bull., v. 15, p. 21-49.

Grunau, H.R., 1965. Radiolarian cherts and associated rocks in space and time: Eclog. Geol. Helv, v. 58, p. 157-208.

Grunau, J.R., Lehner, P., Cleintauar, M.R., Allenbach, P., and Bakker, G., 1975. New radiometric ages and seismic data from Fuerteventura (Canary Islands), Maio (Cape Verde Islands) and Sao Tome (Gulf of Guinea). In
Progress in Geodynamics: Amsterdam (Royal Netherlands Academy of Arts and Science), p. 90-118.

Habib, D., 1972. Dinoflagellate stratigraphy, Leg XI, Deep Sea Drilling Project. In Hollister, C.D., Ewing, J.I., et al., Initial Reports of the Deep Sea Drilling Project, Volume 11: Washington (U.S. Government Printing Office), p. $367-426$.

Hallam, A., 1971. Mesozoic geology and the opening of the North Atlantic: J. Geol., v. 79, p. 129-157.

Hathaway, J.C. and Sachs, P.L., 1965. Sepiolite and clinoptilolite from the mid-Atlantic Ridge: Am. Mineralogist, v. 50, p. 852.

Hayes, D.E., Pimm, A.C., et al., 1972. Initial Reports of the Deep Sea Drilling Project, Volume 14: Washington (U.S. Government Printing Office).

Hayes, D.E. and Rabinowitz, P.D., 1975. Mesozoic Magnetic Lineations and the magnetic Quiet Zone off Northwest Africa: Earth Planet. Sci. Let., v. 28, p. 101-115.

Hayes J.D. and Pitman, W.C., III, 1973. Lithospheric plate motion, sea level changes and climatic and ecological consequences: Nature, v. 246, p. 18-22.

Hollister, C.D., Ewing, J.I., et al., 1972. Initial Reports of the Deep Sea Drilling Project, Volume 11: Washington (U.S. Government Printing Office).

Hurley, P.M., 1968. The conformation of the continental drift: Sci. Am., v. 218, p. 52-64.

Jansa, L.F. and Wade, J.A., 1975. Geology of the continental margin off Nova Scotia and Newfoundland. In Offshore geology of Eastern Canada: Geol. Surv. Canada Paper 7430 , v. 2 , p. 51-105.

Jansa, L.F., 1975. The Central North Atlantic-its birth and disappearance. Ninth Congr. Intern. de Sedimentologie Theme 5, Proc., Nice, v. 2, p. 231-236.

Jansa, L.F. and Wade, J.A., 1975. Paleogeography and sedimentation in the Mesozoic and Cenozoic, Southeastern Canada. In Yorath, C.J., Parker, E.R., and Glass, D.J., (Eds.), Canada's Continental Margins and Offshore Exploration: Canadian Soc. Petrol. Geol. Mem. 4, p. 79-102.

Jefferies, R.P.S. and Minton, P., 1965. The mode of life of two Jurassic species of "Posidionia" (Bivalve): Paleontology, v. 8, p. 156-185.

Jenkyns, H.C., 1971. The genesis of condensed sequences in the Tethyan Jurassic: Lethaia, v. 4, p. 327-352.

Jordan, R., 1974. Salz-und Erdöl/Erdgas-Austritt als Fazies bestimmende Faktoren im Mesozoikum NordwestDeutschlands: Geol. Jahrbuch, Reihe A, Heft 13, 64S.

Kuhry, B., 1972. Stratigraphy and micropaleontology of the Lower Cretaceous in the Subbetic south of Caravaca (Province of Murcia, SE Spain), I and II: K. Nederlands. Akad. Wetensch. Proc., Ser. B., v. 75, p. 194-222.

1975. Observations on filaments from the Subbetic of SE Spain: Rev. Española de Micropaleontol., v. VII, p. 231-243.

Krumbein, W.C. and Garrels, R.M., 1952. Origin and classification of chemical sediments in terms of $p \mathrm{H}$ and oxidation-reduction potentials: J. Geol., v. 60 , p. 1-32.

Lancelot, Y., Hathaway, J.C., and Hollister, Ch.D., 1972. Lithology of sediments from the western North Atlantic, Leg XI, Deep Sea Drilling Project. In Hollister, C.D., Ewing, J.I., et al., Initial Reports of the Deep Sea Drilling Project, Volume 11: Washington (U.S. Government Printing Office), p. 901-950.

Larson, R.L. and Hilde, T.W.C., 1975. A revised time scale of magnetic reversals for the Early Cretaceous and Late Jurassic: J. Geophys. Res., v. 80, p. 2586-2594.

Laubscher, H.P., 1970. Bewegung und Wärme in der alpinen Orogense: Schweiz. Mineral. Petrogr. Mitt., v. 50, p. 503. 
Lehman, R., 1972. Microfossils in thin sections from the Mesozoic deposits of Leg XI, Deep Sea Drilling Project. In Hollister, C.D., Ewing, J.I., et al., 1972. Initial Reports of the Deep Sea Drilling Project, Volume 11: Washington (U.S. Government Printing Office), p. 659-666.

Luterbacher, H., 1972. Foraminifera from the Lower Cretaceous and Upper Jurassic of the Northwestern Atlantic. In Hollister, C. D., Ewing, J.I., et al., 1972. Initial Reports of the Deep Sea Drilling Project, Volume 11: Washington (U.S. Government Printing Office), p. 561594.

Luterbacher, H.P. and Premoli-Silva, I., 1962. Note preliminaire sur une revision du profil de Gubbio, Italie: Riv. Ital. Paleontol., v. 68, p. 253-288.

Luyendyk, B.P., 1974. Gondwanaland dispersal and the early formation of the Indian Ocean. In Davies, T.A., Luyendyk, B.P., et al., Initial Reports of the Deep Sea Drilling Project, Volume 14: Washington (U.S. Government Printing Office), p. 945-951.

Oertli, H.J., 1972. Jurassic ostracodes of DSDP Leg XI (Sites 100 and 105)-preliminary account. In Hollister, C.D., Ewing, J.I., et al., Initial Reports of the Deep Sea Drilling Project, Volume 11: Washington (U.S. Government Printing Office), p. 645-668.

Renz, O., Imlay, R., Lancelot, Y., and Ryan, B.F., 1975. Ammonite-rich Oxfordian Limestones from the Base of the Continental Slope off Northwest Africa: Eclog. Geol. Helv., v. $68 / 2$, p. $431-448$.
Sclater, J.G. and Detrick, R., 1973. Elevation of Midocean Ridges and the Basement Age of JOIDES Deep Sea Drilling Sites: Geol. Soc. Am. Bull., v. 84, p. 1547-1554.

Stahlecker, R., 1934. Necom auf der Kapverden-Insel Maio; Neuen Jahrbuch für Mineralogie: Beil.-Bd. 73, Abt. B, 1934, p. 265-301.

Tucholke, B., Vogt, P., et al., 1975. Glomar Challenger drills in the North Atlantic. Geotimes, p. 18-21.

Veevers, J.J. and Heirtzler, J.R., 1974. Tectonic and paleogeographic synthesis of Leg 27. In Veevers, J.J., Hiertzler, et al., Initial Reports of the Deep Sea Drilling Project, Volume 27: Washington (U.S. Government Printing Office), p. 1049-1054.

von Rad, U. and Rösch, H., 1972. Mineralogy and origin of clay minerals, silica and authigenic silicates in Leg XIV sediments. In Hayes, D.E., Pimm, A.C., et al., Initial Reports of the Deep Sea Drilling Project, Volume 14: Washington (U.S. Government Printing Office), p. $727-$ 752.

Walker, R.G. and Mutti, E., 1973. Turbidite facies and facies associations: In SEPM short course-Turbidites and deep water sedimentation, Anaheim, 1973, p. 119-158.

Walker, T.R., 1974. Formation of red beds in moist climates: a hypothesis: Geol. Soc. Am. Bull., v. 85, p. 633-638.

Zemmels, I., Cook, H.E., and Hathaway, J.C., 1972. X-ray mineralogy studies-Leg XI. In Hollister, C.D., Ewing, J.I., et al., Initial Reports of the Deep Sea Drilling Project, Volume 11: Washington (U.S. Government Printing Office), p. 729-790. 



\section{PLATE 1}

Figure 1 Sample 41-367-39-2, 0-25 cm: Aphanitic basalt with calcite veins (?volcanic basement).

Figure 2 Sample 41-367-40-1, $140 \mathrm{~cm}$ : Vesicular basalt with vesicle filled by ?celadonite. Plagioclase and pyroxene microphenocrysts are intimately intergrown and form feathery aggregates ( $\mathrm{x}$ nic.). Scale bar $=0.7 \mathrm{~mm}$.

Figure 3 Sample 41-367-38-1, $86 \mathrm{~cm}$ : Biomicrite overlying the basalt. Silt size skeletal fragments, Globochaete, Ammodiscus, and calcisphaerulids are dispersed in micritic matrix (ordinary light). Greenish gray limestone unit. Scale bar $=1 \mathrm{~mm}$.

Figure 4 Sample 41-367-35-2, 123-147 cm: Reddish brown nodular limestone with argillaceous laminae. Note thin microbreccia at $131-132 \mathrm{~cm}$ and white recrystallized limestone nodule at $137 \mathrm{~cm}$. Reddish-brown argillaceous limestone unit.

Figure 5 Sample 11-100-7-2, $15 \mathrm{~cm}$ : Argillaceous biomicrite with scattered silt size skeletal debris, Globochaete, and foraminifers (ordinary light). Greenish gray limestone unit. Scale bar $=0.8 \mathrm{~mm}$. 


\section{PLATE 1}
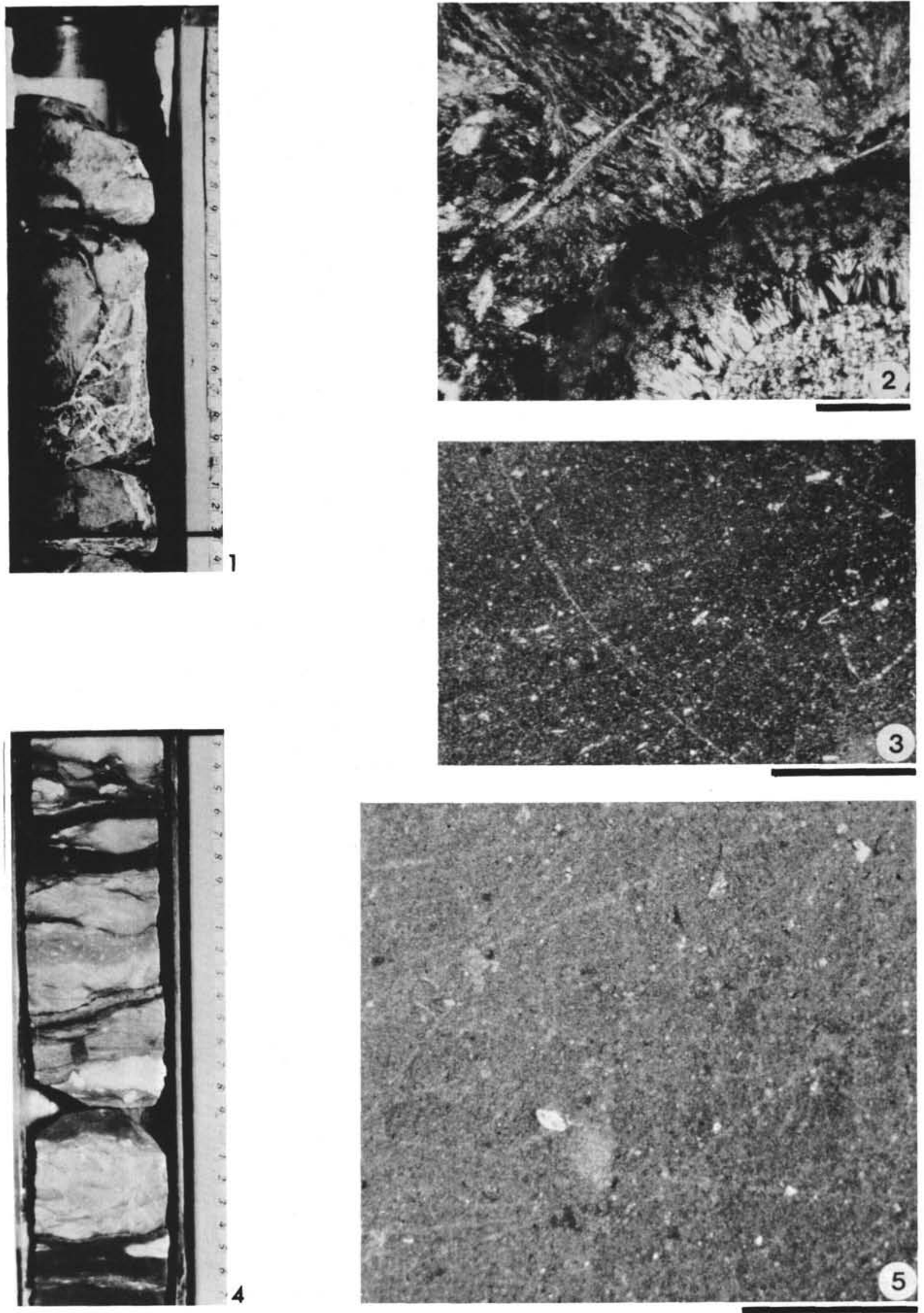


\section{PLATE 2}

Figure 1 Sample 11-100-8-3, $50 \mathrm{~cm}$ : Groundmass of argillaceous biomicrite consisting of dense subhedral neomorphic calcite and rare nannofossils. Greenish gray limestone unit. Scale: 1 division $=10$ microns.

Figure 2 Sample 11-100-8-3, $50 \mathrm{~cm}$ : Laminae of silt size peloid grains, calcisphaerulids, foraminifers, and silt size skeletal debris in a marl ( $x$ nic.). Greenish gray limestone unit. Scale bar $=1 \mathrm{~mm}$.

Figure 3 Sample 11-367-38-2, $40 \mathrm{~cm}$ : Protoglobigerinids and finely disseminated iron sulfide in micrite $(x$ nic.). Greenish gray limestone unit. Scale bar = $0.1 \mathrm{~mm}$

Figure 4 Sample 11-367-38-2, $40 \mathrm{~cm}$ : Globochaete in micritic limestone ( $x$ nic.). ?Greenish gray limestone unit. Scale bar $=0.1 \mathrm{~mm}$.

Figure 5 Sample 41-367-37-1, $144 \mathrm{~cm}$ : Detail of radiolaria replaced by chalcedony and the smaller one by micrite in radiolarian wackestone. Note irregular, wavy, crudely oriented, horizontal hematite stained laminae (x nic.). Radiolarian microfacies, reddish brown argillaceous limestone unit. Scale bar $=0.7 \mathrm{~mm}$.

Figure 6 Sample 41-367-37-1, $144 \mathrm{~cm}$ : Radiolarian wackestone. Radiolarian replaced by chalcedony and/or micrite in hematite stained argillaceous micrite matrix (x nic.). Radiolarian microfacies, reddish brown argillaceous limestone unit. Scale bar $=0.15 \mathrm{~mm}$. 


\section{PLATE 2}
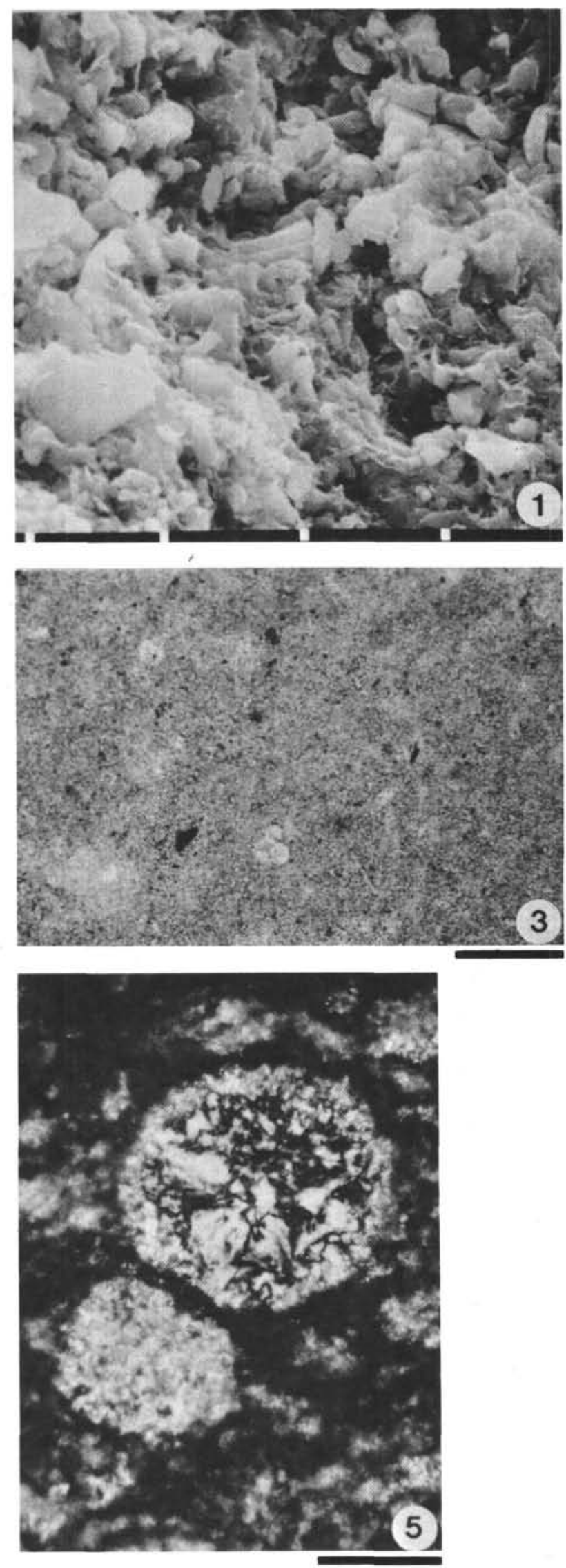
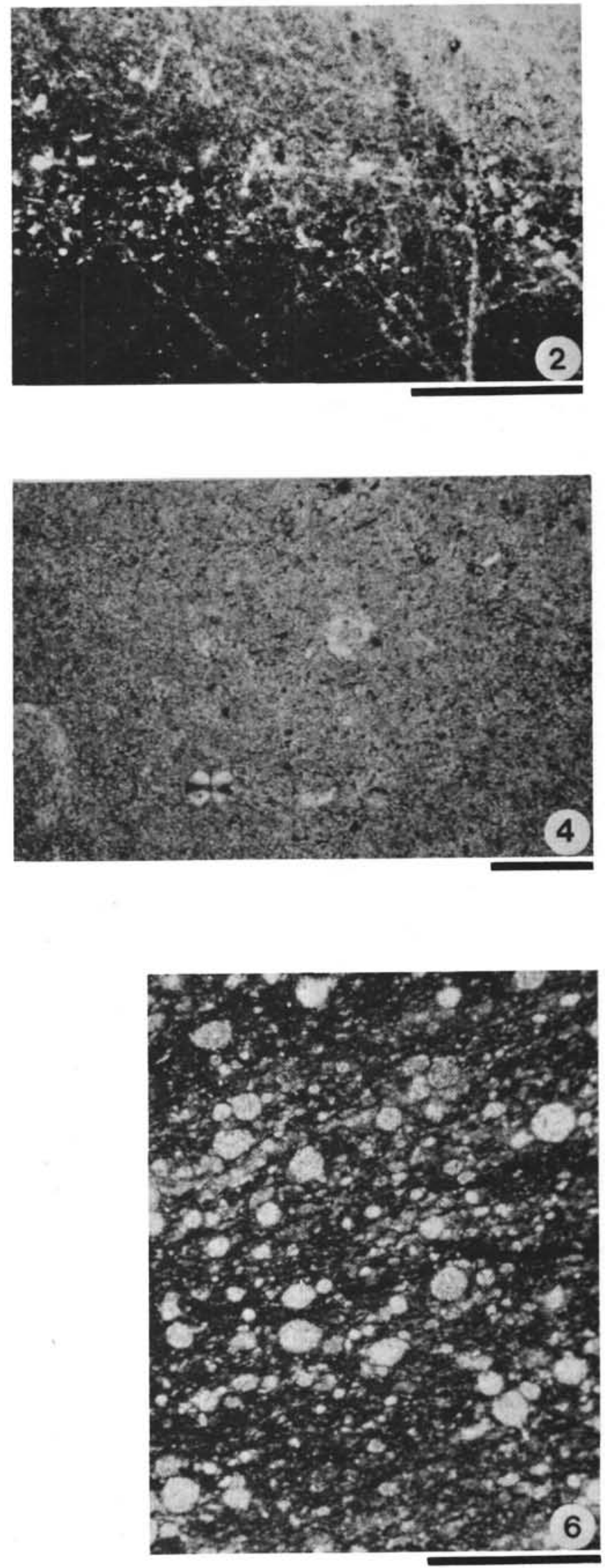


\section{PLATE 3}

Figure 1 Sample 41-367-36-3, $119 \mathrm{~cm}$ : Radiolarian-short filament packstone laminae in the filament microfacies (ordinary light). Reddish-brown argillaceous limestone unit. Scale bar $=1 \mathrm{~mm}$.

Figure 2 Sample 41-367-37-1, $144 \mathrm{~cm}$ : Matrix of the radiolarian wackestone (Plate 2, Figure 6) formed by densely packed neomorphic subhedral calcite, clay minerals, and poorly preserved nannofossils. Radiolarian microfacies, reddish brown argillaceous limestone unit. Scale: division $=10$ microns.

Figure 3 Sample 41-367-36-3, $119 \mathrm{~cm}$ : Filaments with syntaxial sparry calcite overgrowth. Note the wedge shape of the calcite crystals ( $x$ nic.). Filament microfacies, reddish brown argillaceous limestone unit. Scale bar $=0.2 \mathrm{~mm}$.

Figure 4 Sample 11-100-4-1, $31 \mathrm{~cm}$ : Filaments with wedge shape neomorphic sparry calcite overgrowth $(x$ nic.), reddish brown argillaceous limestone unit. Scale bar $=0.1 \mathrm{~mm}$.

Figure 5 Sample 41-367-36-3, $119 \mathrm{~cm}$ : Short filament packstone. Filaments are fragmented as a result of current reworking, reddish brown argillaceous limestone unit. Scale bar $=1.2 \mathrm{~mm}$.

Figure 6 Sample 11-105-37-1, $29 \mathrm{~cm}$ : Filament wackestone with calcisphaerulids (Stomiosphaera; ordinary light). Filament microfacies, reddish brown argillaceous limestone unit. Scale bar $=1 \mathrm{~mm}$. 
PLATE 3
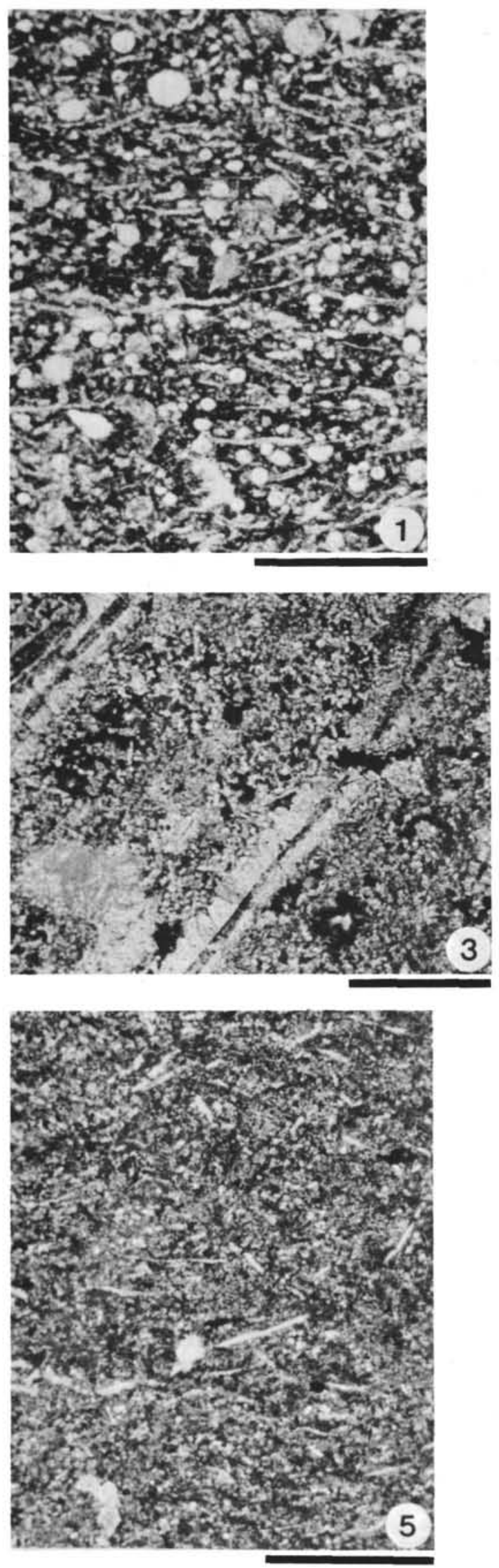
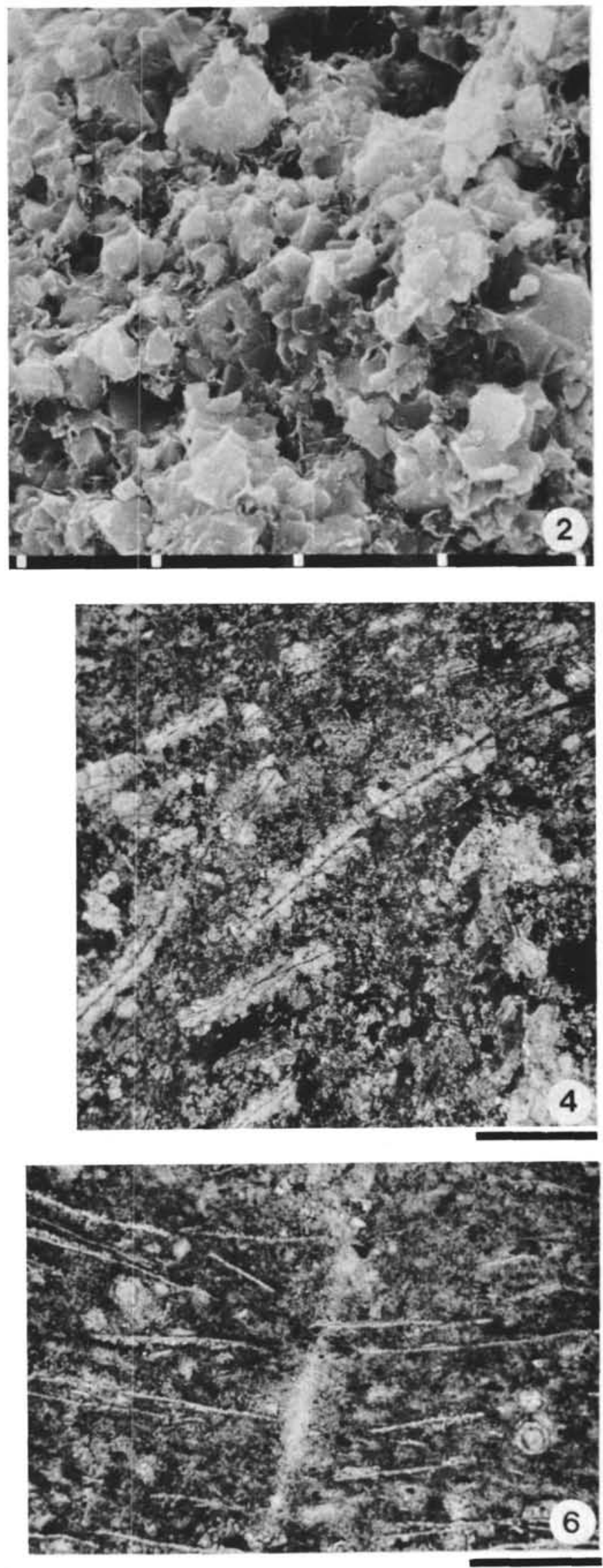


\section{PLATE 4}

Figure 1 Sample 41-367-34-3, 23-47 cm: Dusky red, argillaceous limestone, laminated and thinly bedded, with white neomorphic calcite nodules. The argillaceous laminae separates limestone and porcellanite at $23-26 \mathrm{~cm}$. Note an aptychus at, 27 $\mathrm{cm}$. Saccocoma microfacies, reddish brown argillaceous limestone unit.

Figure 2 Sample 41-367-35-2, $22 \mathrm{~cm}$ : Hematite stained clayey laminae is overlain by skeletal wackestone with fragments of the pelagic crinoid-Saccocoma, calcisphaerulids, silt-size skeletal debris, and calcite spherules. Lamination and parallel orientation of the skeletal debris indicates slight reworking of the sediment by bottom currents; (ordinary light), Saccocoma microfacies, reddish brown argillaceous limestone unit. Scale bar $=1$ $\mathrm{mm}$.

Figure 3 Sample 41-367-36-3, $119 \mathrm{~cm}$ : Moderately recrystallized argillaceous limestone without effective porosity. Note poorly preserved nannofossils with calcite overgrowth in the central part, neomorphic subhedral calcite and clay minerals. Filament microfacies, reddish brown argillaceous limestone unit. Scale: 1 division $=3$ $\mu \mathrm{m}$.

Figure 4 Sample 11-105-33-4, $55 \mathrm{~cm}$ : Saccocoma wackestone; composed of fragments of pelagic crinoid with syntaxial calcite overgrowth, Radiolaria replaced by sparry calcite and hematite stained argillaceous micrite (ordinary light). Saccocoma microfacies, reddish brown argillaceous limestone unit. Scale bar $=1 \mathrm{~mm}$.

Figure 5 Sample 11-100-2-3, $93 \mathrm{~cm}$ : Argillaceous skeletal wackestone with fragments of Saccocoma, abraded aptychi (A), calcisphaerulids, peloids, and a clayey laminae (ordinary light). Saccocoma microfacies, reddish brown argillaceous limestone unit. Scale bar $=1 \mathrm{~mm}$. 

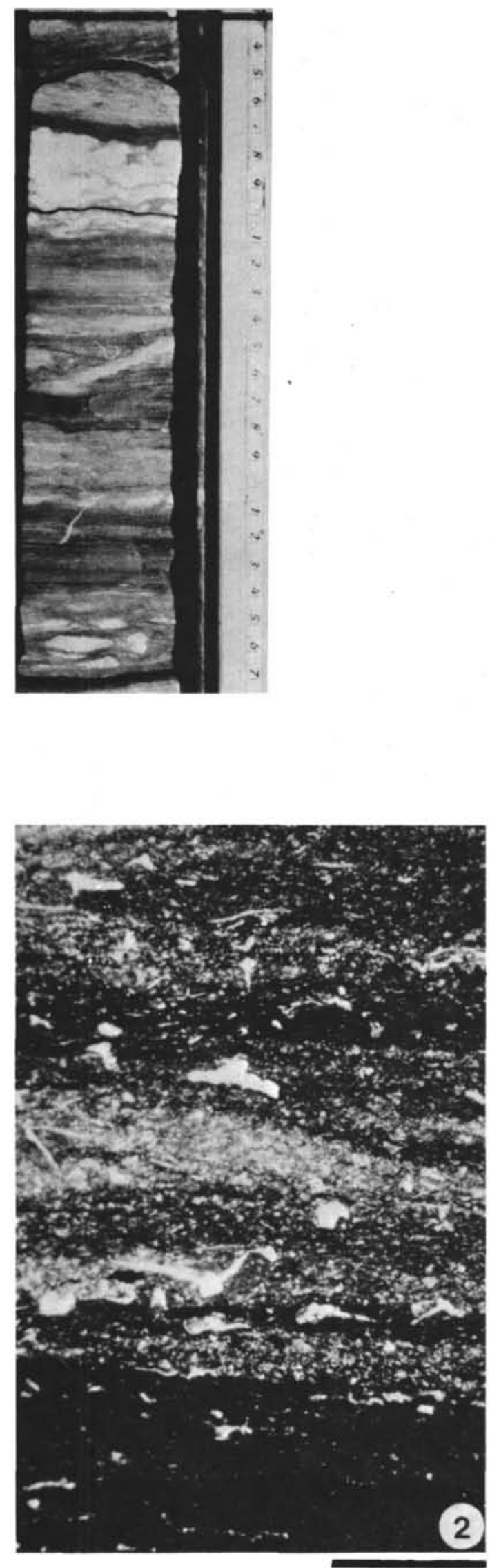

PLATE 4
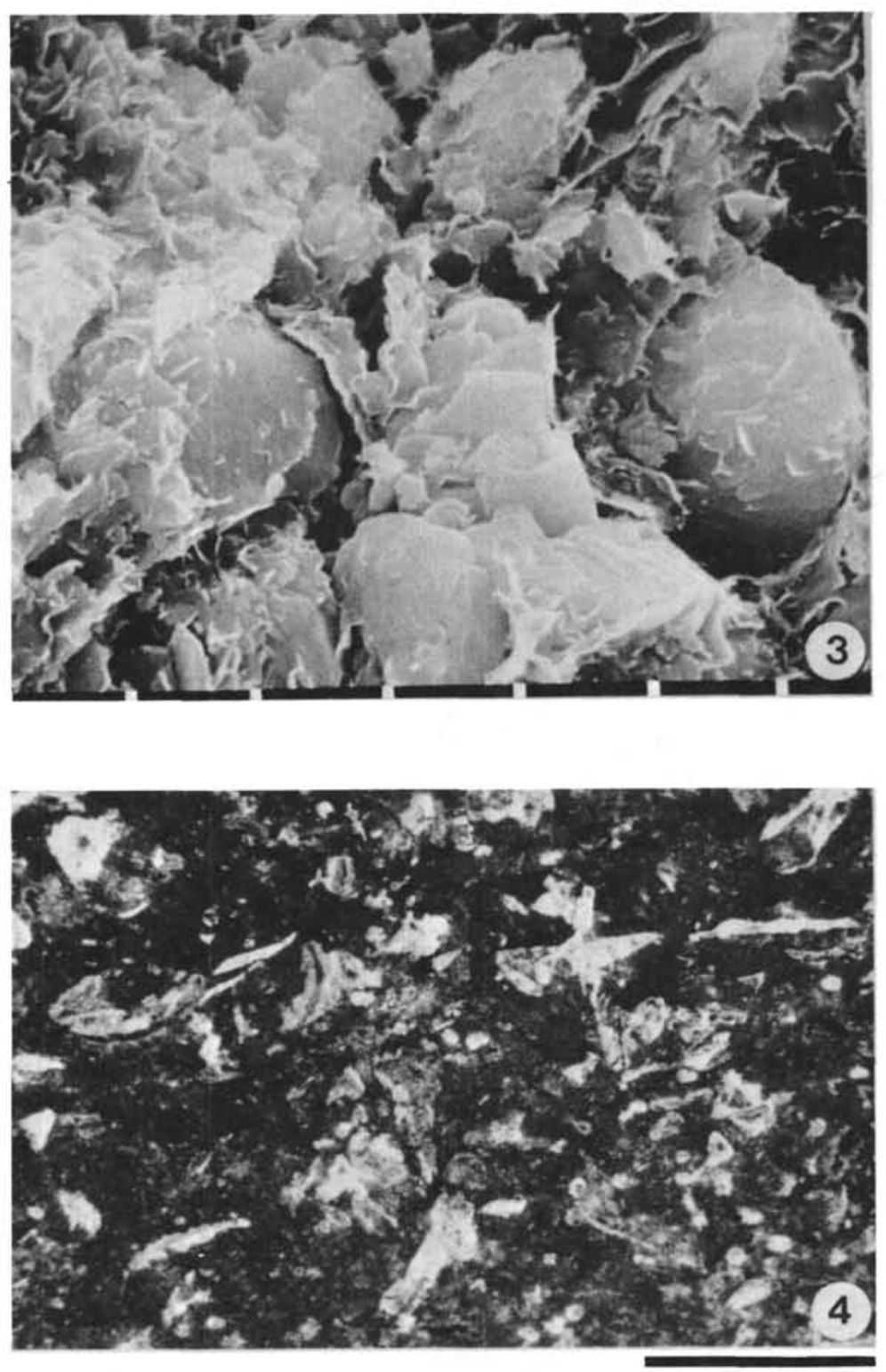


\section{PLATE 5}

Figure 1 Sample 41-367-33-1, $17 \mathrm{~cm}$ : Dense, welded euhedral neomorphic calcite with minor clay, and occasionally preserved nannofossil indicating recrystallization of the limestone. Very low intercrystalline porosity. Saccocoma microfacies, reddish brown argillaceous limestone unit. Scale: division $=3 \mu \mathrm{m}$.

Figure 2 Sample 11-105-33-4, $51 \mathrm{~cm}$ : Dense, welded neomorphic calcite with poorly preserved nannofossils which show strong dissolution (upper left corner), and calcite overgrowth in the center of the nannofossil. Porosity is obliterated by diagenetic alteration of the carbonate. Saccocoma microfacies, reddish brown argillaceous limestone unit. Scale: division $=3 \mu \mathrm{m}$.

Figure 3 Sample 41-367-29-2, $1 \mathrm{~cm}$ : Intensively recrystallized nannofossil limestone, composed of partially welded neomorphic euhedral calcite crystals and rare nannofossils, some of which show dissolution. Low intercrystalline porosity. Lower part of the white chalky limestone unit. Scale: division $=10 \mu \mathrm{m}$.

Figure 4 Sample 11-105-33-1, $81 \mathrm{~cm}$ : Nannofossil limestone with an open calcisphaerulid which has short stubby calcite overgrowth. White chalky limestone unit near to its lower boundary. Scale: division = $30 \mu \mathrm{m}$.

Figure 5 Sample 41- 367-26-4, $52 \mathrm{~cm}$ : Nannofossil limestone with loosely packed nannofossils. Nannofossils show dissolution and recrystallization with minor neomorphic calcite in the voids. Note attached subhedral calcite crystals on nannofossil surface and interpenetration of the calcite crystal and fossil fragments in the lower left corner. (Compare difference in the intensity of the diagenetic alteration between Figures 3 and 5.) High interparticle porosity. Upper part of the white chalky limestone unit. Scale: division $=3$ $\mu \mathrm{m}$.

Figure 6 Sample 11-105-33-1, $81 \mathrm{~cm}$ : Detail of Figure 4 shows intensive recrystallization of nannofossils and neomorphic euhedral calcite filling the interskeletal voids. Low intercrystalline porosity. Scale: division $=3 \mu \mathrm{m}$. 


\section{PLATE 5}
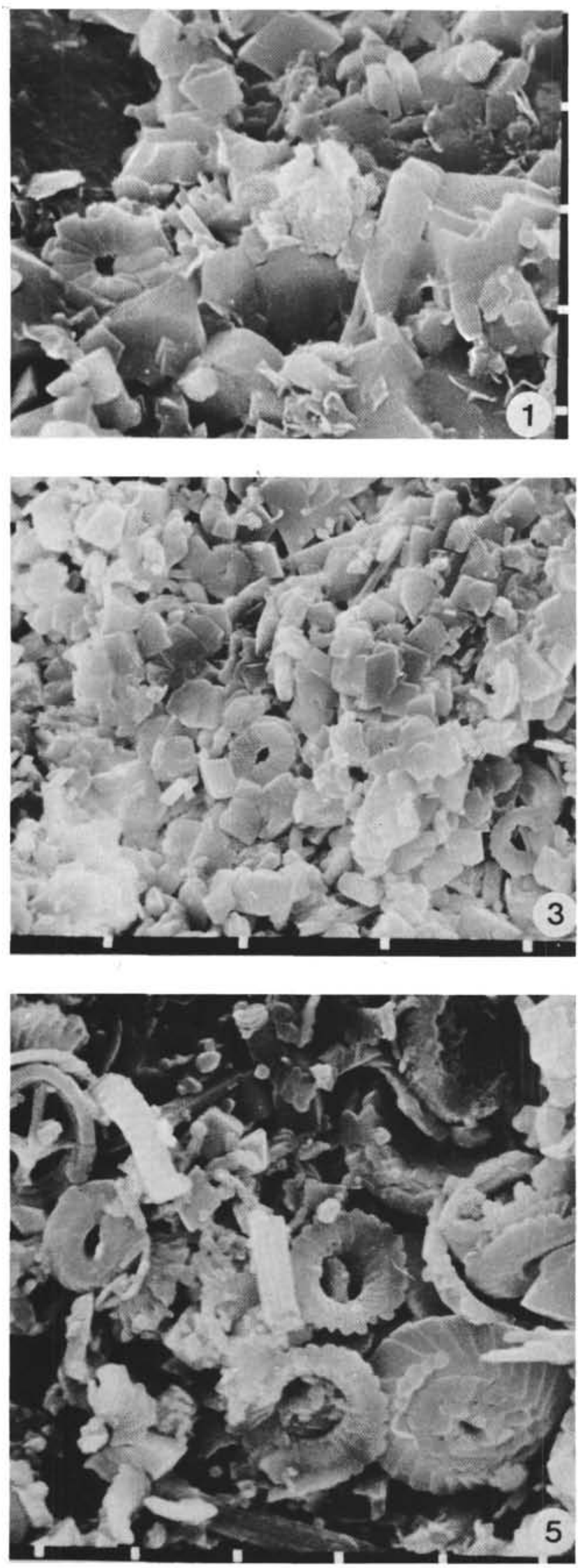
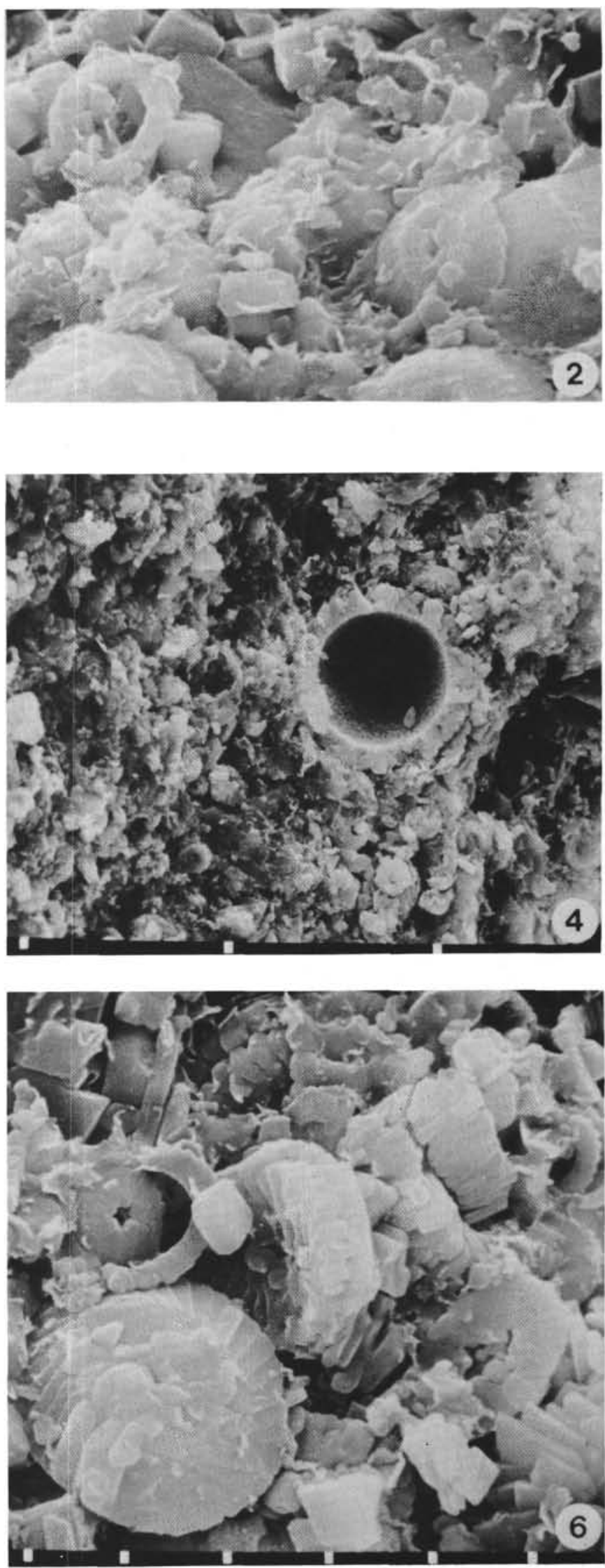


\section{PLATE 6}

Figure $1 \quad$ Sample 41-367-25-3, 33-48 cm: Medium gray bed of marl in light gray, slightly bioturbated nannofossil limestone. Marl is poorly laminated and both boundaries are sharp. Upper part of the white chalky limestone unit.

Figure 2 Sample 41-367-25-4, 48-73 cm: Olive-gray, finely laminated argillaceous limestone with light gray limestone bed in the center. Contacts between beds are transitional. Upper part of the white chalky limestone unit.

Figure 3 Sample 41-367-32-5, $62 \mathrm{~cm}$ : Biomicrite with calpionellids and minor sparry calcite replaced Radiolaria in contact with porcellanite-ordinary light. Base of the white chalky limestone unit. Scale bar $=0.7 \mathrm{~mm}$.

Figure 4 Sample 41-367-32-5, $62 \mathrm{~cm}$ : Detail of Figure 3, shows several sections of calpionellids-ordinary light. Scale bar $=0.1 \mathrm{~mm}$.

Figure 5 Sample 11-105-33-1, $81 \mathrm{~cm}$ : Calpionellids and calcisphaerulids in nannofossil limestone (for detail see Plate 5, Figures 4 and 6), (ordinary light). Base of the white chalky limestone unit. Scale bar $=0.1 \mathrm{~mm}$.

Figure 6 Sample 11-105-32-1, 130-133 cm: Intraclast of light gray micrite with calpionellids and sparry calcite replaced Radiolaria enclosed in brownish stained biomicrite, ordinary light. Near the base of the white chalky limestone unit. Scale bar $=1 \mathrm{~mm}$. 


\section{PLATE 6}
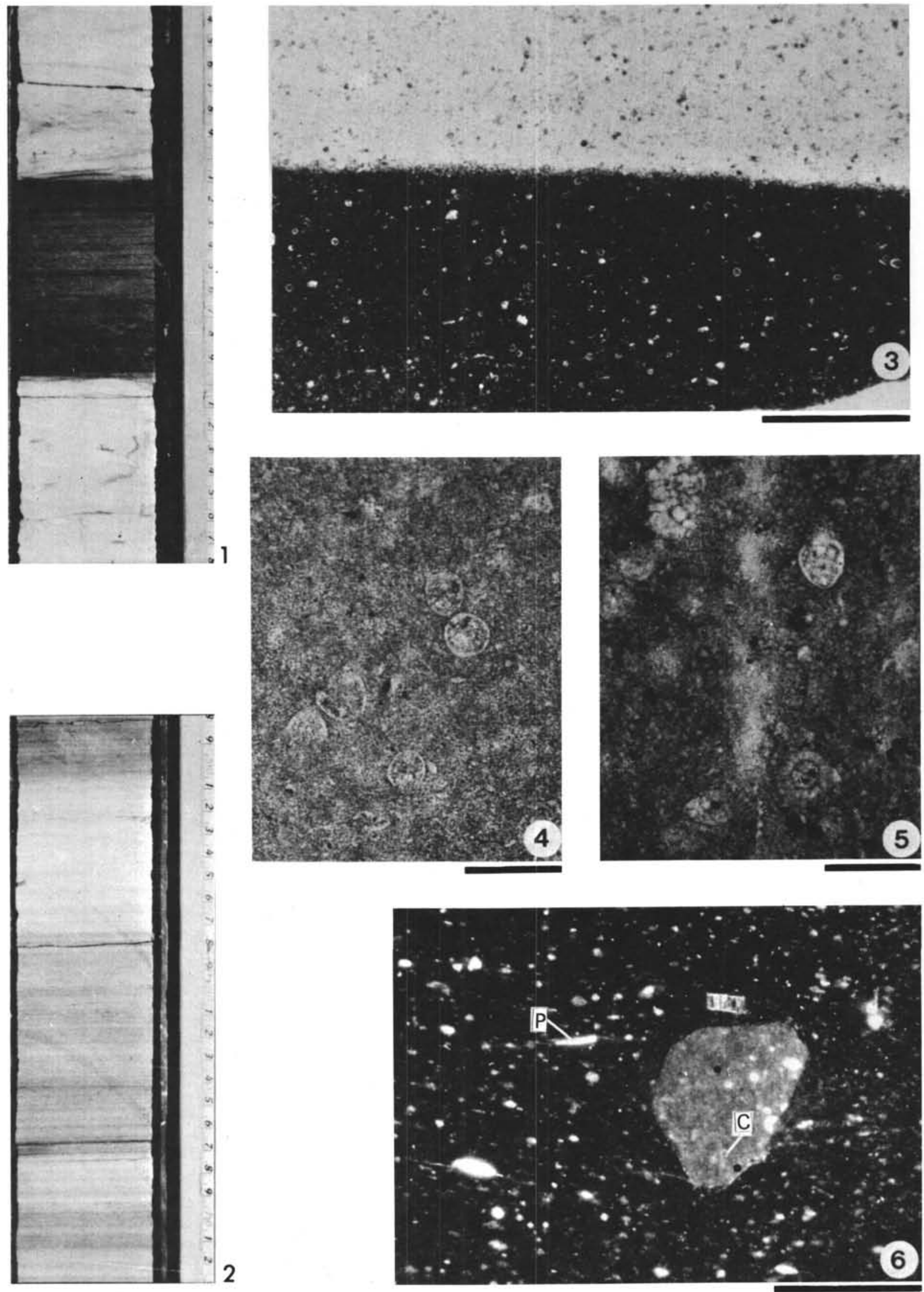


\section{PLATE 7}

Figure 1 Sample 41-367-31-2, $120 \mathrm{~cm}$ : Radiolaria-bearing nannofossil limestone. Radiolaria are replaced by sparry calcite (x nic.). Light gray limestone bed in the white chalky limestone unit. Scale bar $=0.7$ $\mathrm{mm}$.

Figure 2 Sample 41-367-28-1, $110 \mathrm{~cm}$ : Fine laminated olivegray bituminous, micritic limestone. The thin section shows concentration of sapropel into thin, wavy laminae, pyrite replaced Radiolaria and euhedral dolomite crystals and micritic matrix (ordinary light). White chalky limestone unit. Scale bar $=0.1 \mathrm{~mm}$.

Figure 3 Sample 41-367-26-4, $52 \mathrm{~cm}$ : Bituminous argillaceous micrite, poorly laminated, with dispersed and also concentrated terrigenous quartz silt in lenses ( $x$ nic.). Dark gray bed near the top of the white chalky limestone unit. Scale bar $=$ $1 \mathrm{~mm}$.

Figure 4 Sample 41-367-24-3, $78 \mathrm{~cm}$ : Variegated claystone, characteristic by lack of biogenic carbonate ( $\mathrm{x}$ nic.). Black bituminous shale unit. Scale bar $=0.4$ $\mathrm{mm}$.

Figure 5 Sample 41-367-22-3, $93 \mathrm{~cm}$ : Sapropel and euhedral ferroan dolomite crystals in argillaceous matrix ( $\mathrm{x}$ nic.). Black bituminous shale unit. Scale bar $=0.1$ $\mathrm{mm}$.

Figure 6 Sample 41-367-20-4, $38 \mathrm{~cm}$ : Thin turbidite bed of graded foraminifera grainstone composed of foraminifers, phosphatic fish debris and pyrite. Grainstone grades upward into bituminous shale. The lower contact of the bed is sharp (ordinary light), black bituminous shale unit. Scale bar $=1$ $\mathrm{mm}$. 
PLATE 7
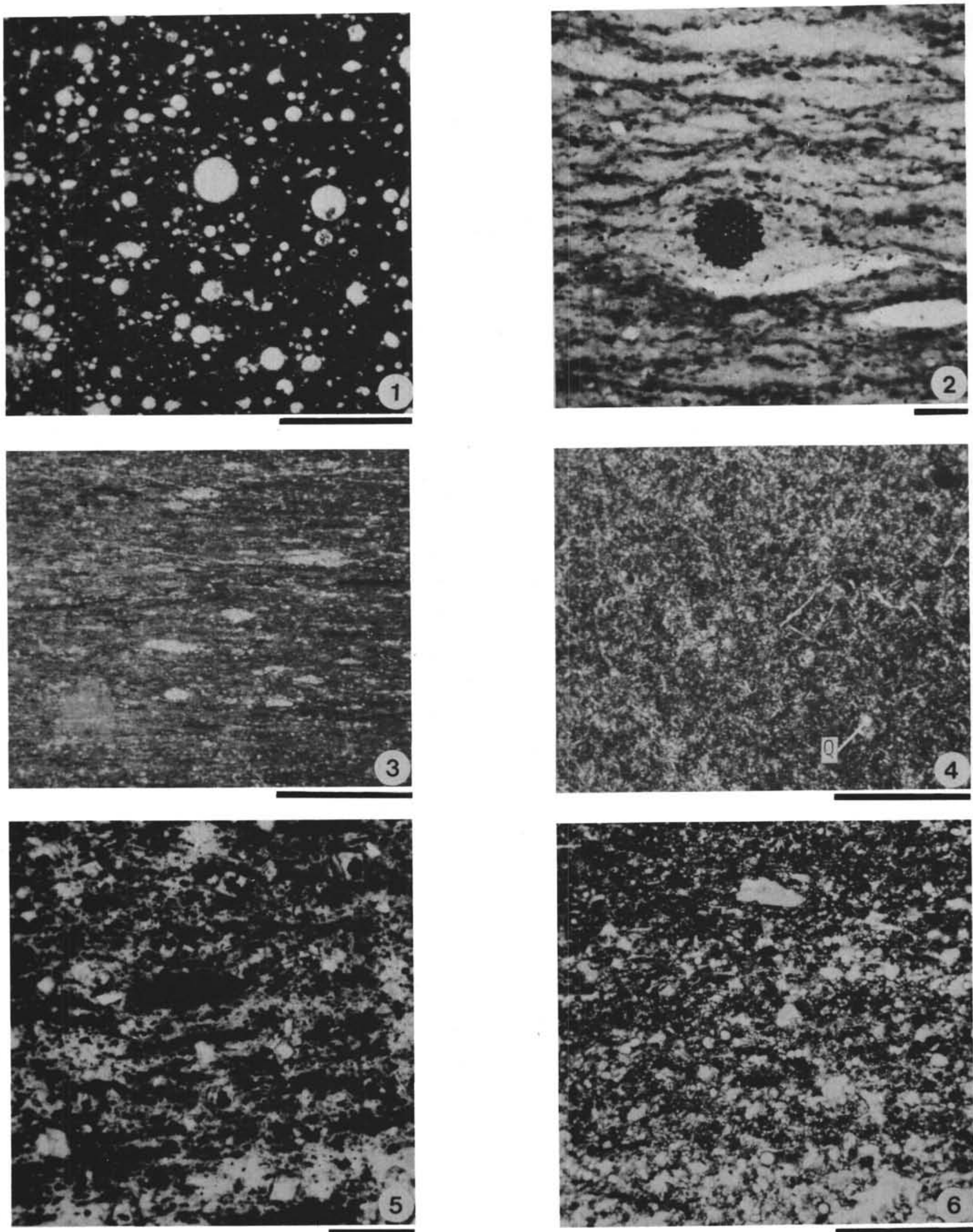


\section{PLATE 8}

Figure 1 Sample 41-367-22-2, $73 \mathrm{~cm}$ : Claystone with authigenic pyrite and quartz silt. Black bituminous shale unit. Scale: division $=10 \mu \mathrm{m}$.

Figure 2 Sample 41-367-20-4, $38 \mathrm{~cm}$ : Foraminifera turbidite bed (see Plate 7, Figure 6). Foraminifer tests are well preserved, some are fragmented and welded by neomorphic sparry calcite. Black bituminous shale unit. Scale: division $=30 \mu \mathrm{m}$.

Figure 3 Sample 41-367-22-3, $93 \mathrm{~cm}$ : Turbidite laminae composed of fragmented nannofossils showing high dissolution. Black bituminous shale unit. Scale: division $=3 \mu \mathrm{m}$.

Figure 4 Sample 41-370-23-1, $98 \mathrm{~cm}$ : Claystone with occasionally well preserved nannofossils. Greenish claystone unit. Scale: division $=3 \mu \mathrm{m}$.

Figure 5 Sample 41-370-23-1, $98 \mathrm{~cm}$ : Foraminifera, with one chamber filled by pyrite micronodules and authigenic clay. Black bituminous shale unit. Scale: division $=30 \mu \mathrm{m}$.

Figure 6 Sample 41-367-15-3, $75 \mathrm{~cm}$ : Variegated claystone. Note loose packing and lack of preferential orientation of clay minerals and complete lack of biogenic carbonate. Greenish claystone unit. Scale: division $=1 \mu \mathrm{m}$. 
PLATE 8
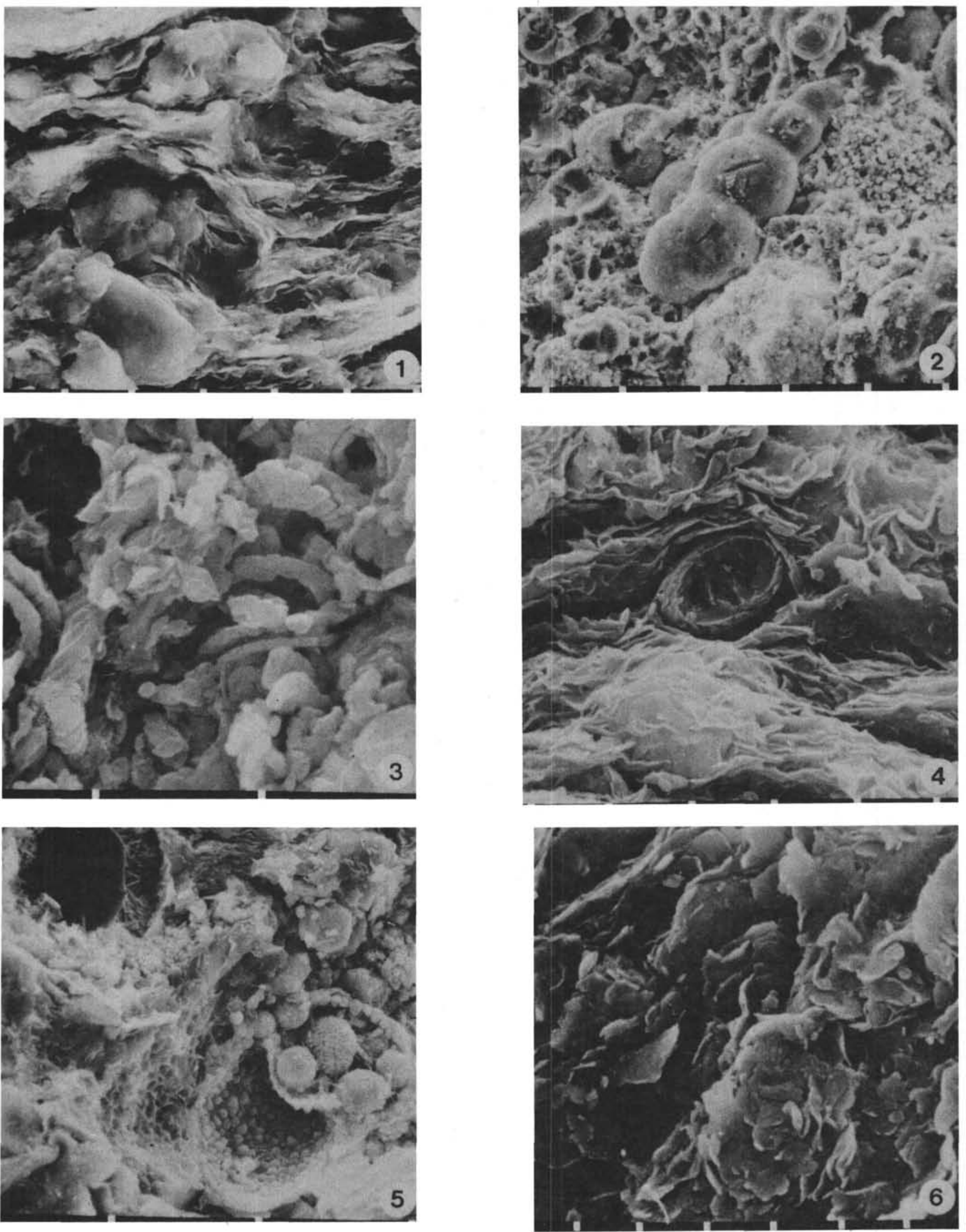


\section{PLATE 9}

Figure 1 Sample 41-367-46-5, 98-12 cm: Typical core of the black shale, showing its structureless character. Black bituminous shale unit.

Figure 2 Sample 41-369A-41-2, 118-122 cm: Olive-black nannofossil marl with thin laminae and lenses of white nannofossil chalk. Contact of the marl with overlying white argillaceous chalk representing a slump is sharp. Olive-black silty nannofossil marllithofacies, black bituminous shale unit.

Figure 3 Sample 41-370-35-4, 98-122 cm: Dark gray nannofossil-bearing shale with thin laminae of fine-grained sandstone and thin bed of intraclast conglomerate, grayish green claystone-intraclast sandstone unit.

Figure 4 Sample 41-369A-38-2, 23-47 cm: Argillaceous chalk, light gray, intensively bioturbated, greenish claystone unit.

Figure 5 Sample 41-368-34-2, 23-48 cm: Cyclic repetition of the dark olive and greenish gray claystones. Note the sharp boundary at the base of the dark claystone beds, an upper transitional boundary and difference in the intensity of bioturbation. The dark claystone beds representing clayey tail of turbidites, greenish claystone unit. 


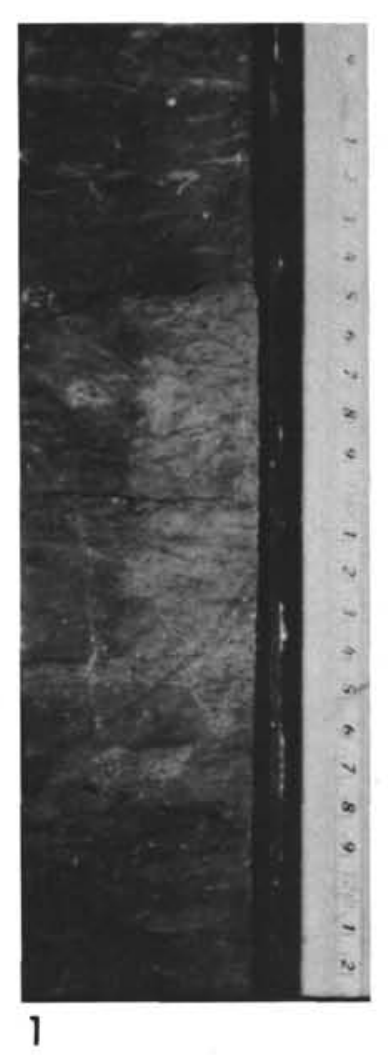

PLATE 9
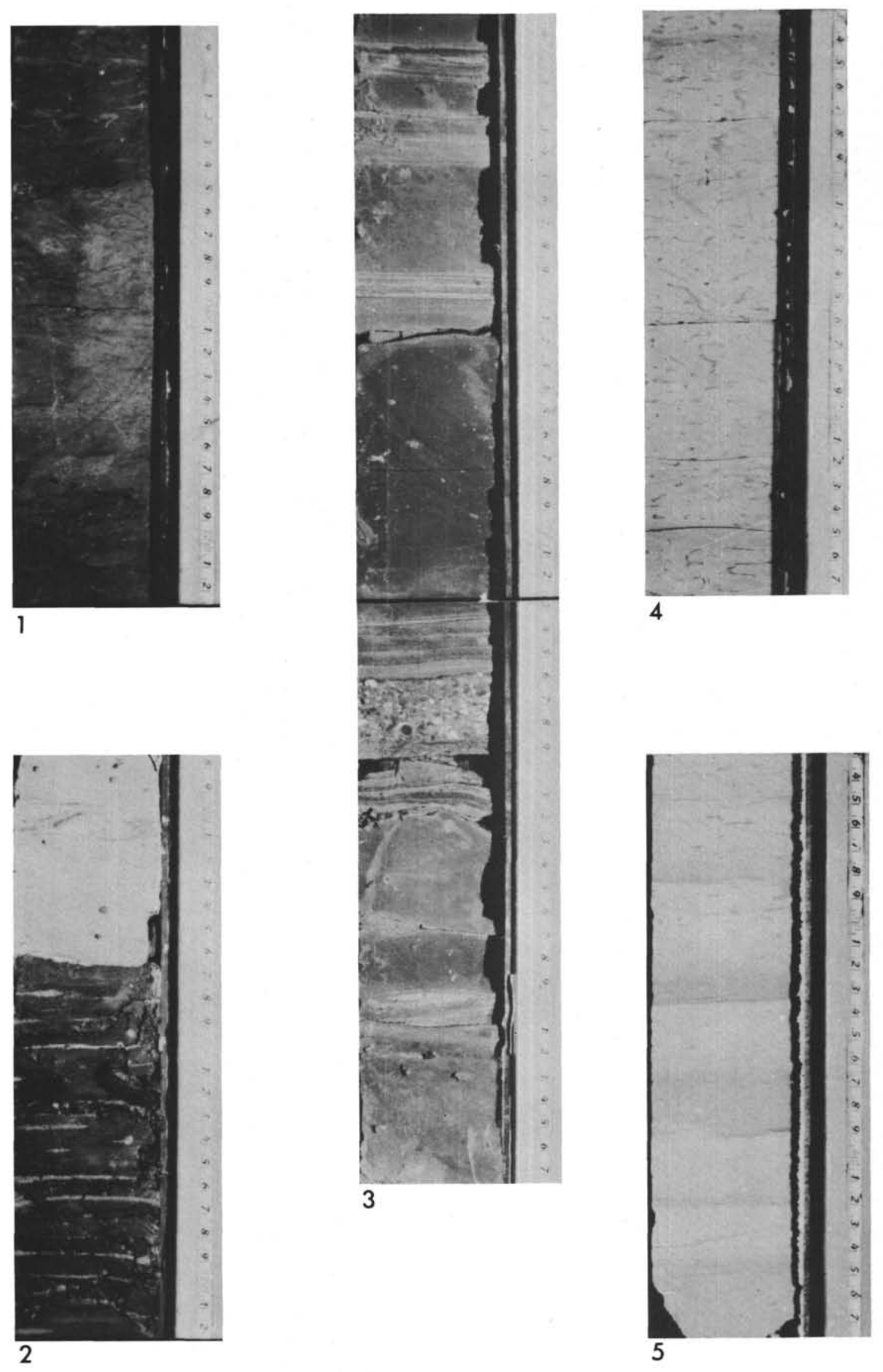


\section{PLATE 10}

Figure 1 Sample 41-370-51-2, $55 \mathrm{~cm}$ : Argillaceous siltstone overlain, with a sharp contact, by medium-grained intraclast sandstone. The sandstone is comprised of micritized skeletal fragments, oolites (O), mudstone intraclasts, calcisphaerulids (C), echinoderm fragments, otholiths (Ot) and pyrite, cemented by ferroan sparry calcite. Shallow water origin of fragments indicate that the sandstone was deposited by turbidity currents (ordinary light). Grayish green claystone-intraclast sandstone unit. Scale bar $=1 \mathrm{~mm}$.

Figure 2 Sample 41-370-35-2, $105 \mathrm{~cm}$ : Poorly sorted, coarse-grained sandstone turbidite, composed of subangular grains of glauconite $(G)$, peloidskeletal grainstone and micritic limestone intraclasts, micritized skeletal fragments, pyrite (P), and basic volcanics fragments (V); all cemented by ferroan sparry calcite (ordinary light). Grayish green claystone-intraclast sandstone unit. Scale bar $=1 \mathrm{~mm}$.

Figure 3 Sample 41-370-42-4, $141 \mathrm{~cm}$ : Two generations of calcite cement in the intraclast sandstone. The first generation is drusy low sparry calcite rim cement (R) with later void filling ferroan sparry calcite (stained, ordinary light). Grayish green claystone intraclast sandstone unit. Scale bar $=1 \mathrm{~mm}$.

Figure 4 Sample 41-370-47-2, $78 \mathrm{~cm}$ : Heavy minerals, pyrite, and rare shale intraclasts concentrated into laminae in fine-grained quartzose sandstone. Note a calcisphaerulid (C) with the chamber filled by pyrite. Concentration of heavy minerals indicates bottom current reworking of the turbidite (ordinary light). Grayish-green claystoneintraclast sandstone unit. Scale bar $=0.5 \mathrm{~mm}$. 
PLATE 10
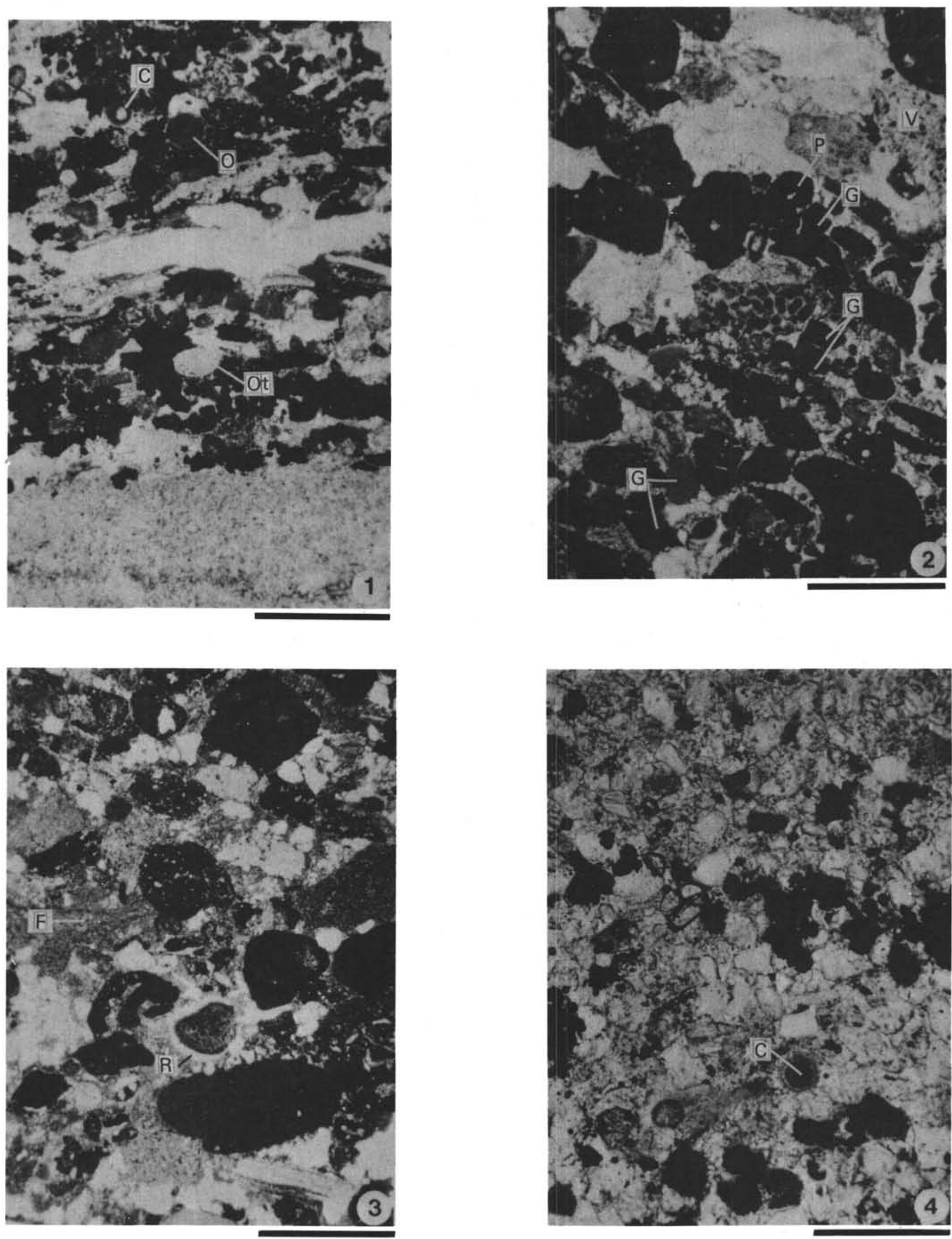